\title{
Collaborative Innovation in Family Firms: Past Research, Current Debates and Agenda for Future Research
}

\author{
Feranita Feranita \\ Department of Entrepreneurship, Strategy and innovation \\ Lancaster University Management School \\ Lancaster (UK), LA1 4YX \\ f.feranita@lancaster.ac.uk \\ Josip Kotlar \\ Department of Entrepreneurship, Strategy and innovation \\ Lancaster University Management School \\ Lancaster (UK), LA1 4YX \\ Tel. +44 (0)1524 594045; j.kotlar@lancaster.ac.uk
}

\author{
Alfredo De Massis \\ (corresponding author) \\ Professor of Entrepreneurship and Family Business \\ Free University of Bozen-Bolzano (Italy), School of Economics \& Management \\ Piazza Università 1, 39100 Bozen/ Bolzano (Italy) \\ Tel. + 390471013002 \\ alfredo.demassis@unibz.it \\ and \\ Department of Entrepreneurship, Strategy \& Innovation, Lancaster University Management \\ School (UK)
}

Accepted for publication in Journal of Family Business Strategy

\section{Acknowledgements}

The authors acknowledge the financial support received from the Research and Development Management Association (RADMA) and MGF Ltd, a privatelyowned family firm in UK. 


\title{
Collaborative Innovation in Family Firms: \\ Past Research, Current Debates, and an Agenda for Future Research
}

\begin{abstract}
Collaborative innovation can boost family firms' innovation performance by enabling them to tackle their resource constrains and tap into knowledge, financial capital, technology, and information from other organizations. Unfortunately, existing research on collaborative innovation in family firms is still in its infancy. We systematically review and organize fragmented findings and arguments from prior research along three perspectives: strategic, transactional, and relational. In doing so, we provide a summary of the current state-of-the-art in this literature, point to the importance of collaborative innovation to resolve the innovation dilemma in family firms and identify promising opportunities for future research.
\end{abstract}

\section{INTRODUCTION}

Collaborative innovation is becoming increasingly important because it enables firms to tackle their resource constraints and tap into the knowledge from other organizations in order to boost their innovation potential (Hitt et al., 2000). The importance of collaborative innovation can be seen from its positive effect on innovation performance both at collaboration level, measured by joint patent/invention (Kim \& Song, 2007; Hoang and Rothaermel, 2005), and firm level, measured by items including new patents applied, new products developed, new/modified product/service/processes introduced, industry awards, and innovation radicalness (Fang, 2011; Kang \& Park, 2012; Keil et al., 2008; Lahiri \& Narayanan, 2013; Mention, 2011; Sampson, 2005; Soh, 2010; Stuart, 2000; Tomlinson, 2010; Un et al., 2010; Vasudeva et al., 2013; Zeng et al., 2010). The positive effect of collaborative innovation can also be found in financial performance at firm level, measured by items such as net income, profitability, sales, growth, and market share (Lahiri \& Narayanan, 2013; 
Lavie \& Miller, 2008; Lu \& Beamish, 2001; Singh \& Mitchell, 2005). Research on collaborative innovation has grown substantially over the last three decades, with more than 52,000 collaborations analyzed from 1990 to 2005 (Schilling, 2009). The growing importance of collaboration is also witnessed by the rapid diffusion of 'open innovation' paradigms among innovation practitioners, where firms leverage on external sources rather than relying entirely internally (Chesbrough, 2006).

This trend is particularly important for family firms, and researchers have called for more insights on how family firms embrace an "open" approach to collaborations in order to innovate (Kellermanns, 2016). Due to the unwillingness of family members to lose control (e.g., Gomez-Mejia et al., 2007), resource constraints shaped by their governance structures and size (e.g., Carney, 2005), distinctive aspects of their social capital (e.g., Arregle et al., 2007), and long-term orientation (Miller \& Le Breton-Miller, 2005), collaborative innovation can be an effective means to overcoming innovation barriers and a major source of competitive advantage for innovation in family firms (De Mattos et al., 2013; Hitt et al., 2000; Sirmon et al., 2008). Family conglomerates are a good example where such form of family business diversifies into a wide variety of industries to have access to resources needed and yet retain family control. However, less is known on how family firms tackle the issue of the unwillingness to lose control when collaborating with external parties, such as the governance mechanisms used to prevent knowledge leakage. Also, how family firms can capitalize on the unique family firm characteristics like social capital and long-term orientation to build successful collaborative innovation is still far from being understood.

Existing research on innovation in family firms splits into two broad areas of inquiry, one focusing on innovation inputs (e.g., $R \& D$ investments) and the other on innovation outputs (e.g., new product introduction, patent registrations) (De Massis et al., 2013). Studies focusing on innovation inputs have shown that family firms generally invest less in 
innovation than nonfamily firms (Chen \& Hsu, 2009; Chrisman \& Patel, 2012; Czarnitzki \& Kraft, 2009; Kotlar et al., 2013; Munari et al., 2010). However, research on innovation outputs has shown that family firms achieve higher innovation performance than nonfamily firms (e.g., Block, 2012; Czarnitzki \& Kraft, 2009). This points to an apparent paradox named by some scholars as the "family innovation dilemma" (Duran et al., 2015). Therefore, family business scholars are highly interested in understanding why and how family firms can "do more with less" (e.g., De Massis et al., 2017) and outperform nonfamily firms despite lower innovation inputs.

In this review article, we argue that external sources of innovation can be particularly important to address this dilemma, hence we focus on the critical role of collaboration in explaining the innovative performance of family firms. Drawing on the existing research on innovation collaborations (Das \& Teng, 2000; Gulati, 1995; Kale \& Singh, 2009; Un et al., 2010) and consistent with prior family business research on the topic (Block, 2012; Matzler et al., 2015; Munoz-Bullon \& Sanchez-Bueno, 2011), we define collaborative innovation as a form of inter-firm relationship that involves the exchange and sharing of information, knowledge, technology, and resources with external parties in order to achieve innovation. Collaborative innovation includes alliances, joint ventures, technology exchange, contractual agreements, licensing, and partnerships, and encompasses a broad spectrum of external parties such as customers, suppliers, competitors, universities and research institutes.

During the past few years, scholars have started looking at the collaborative aspects in the innovation strategy and operations of family firms, particularly focusing on how collaborations with external organizations lead to access of resources like capital, information, knowledge, and technology. For example, leaning on resource based view (RBV) and behavioral theory, Classen et al. (2012) have examined how family involvement influences the depth and breadth of search for external resources leading to innovation in 
family SMEs. Block and Spiegel (2013) have studied the role of family firms in promoting knowledge spillovers within a region, where the propensity of family firms to collaborate with other firms have possibly contributed to the regional innovation output by boosting successful patent applications. Others have examined the behavioral barriers that prevent family firms from acquiring external technology (Konig et al., 2013; Kotlar et al., 2013). However, although this body of research is rich in insights, existing literature remains highly fragmented in terms of theoretical perspectives, constructs and relationships, and empirical approaches. Fragmentation is a typical trait of research fields that undergo an initial "excitement" and growth phase, but the lack of a coherent framework can inhibit the accumulation of knowledge and hamper the maturation of the field (Hirsch \& Levin, 1999). The purpose of this article is to assist the development of the field by systematically reviewing and organizing existing research on collaborative innovation in family firms and integrating findings and arguments from prior research. Our ultimate goal is to guide future academic work towards a more coherent and robust understanding of collaborative innovation in family firms. In order to achieve this goal, we organize the existing literature on collaborative innovation into categories based on emerging themes and patterns to identify research gaps and guide future research.

We do so in three major steps. First, we define and discuss key constructs and assumptions in prior research on collaborative innovation and outline a guiding framework for our subsequent analysis of collaborative innovation in family firms (Gulati, 1995; Kale \& Singh, 2009). In doing so, we identify three streams of perspectives on collaborative innovation: strategic, transactional, and relational. We note that, while research on collaborative innovation from the general management field has picked up its pace back in the 1990's, this vast literature has been developed without explicitly considering family firms, thereby overlooking the unique characteristics of family firms and their distinctive 
advantages and challenges in the context of collaborative innovation. Thus, in the second step, we synthesize prior research findings and arguments in relation to collaborative activities undertaken by family firms in achieving innovation and map them onto the three streams of perspectives on collaborations outlined earlier. Through this process, we develop a framework that integrates the different theoretical perspectives used in examining the topic of collaborative innovation in family firms. Finally, we draw from this framework to identify the research gaps and potential paths to guide future research. These gaps point to important but nonetheless little known antecedents and intervening factors that can possibly enable or constrain collaborative innovation in family firms. Overall, we thus contribute to an integrative and systematic understanding of collaborative innovation in family business, offer a framework of current thinking categorized by theoretical perspectives, and provide a coherent research agenda that we hope will assist the creation of cumulative knowledge in future work.

By systematically reviewing the past and present debates on collaborative innovation in family firms, and integrating the literature from the fields of family business and general management, we intend to contribute to existing literature in two main ways. First, we aim to offer a solid ground for opening up a new agenda for research that sparks and guides the conversation on collaborative innovation in family firms. Such guiding framework can help direct future research toward the maturation of the field, including the use of coherent theoretical perspectives, valid measurements, and an appreciation of different study contexts in addressing research questions and building cumulative knowledge (Hirsch \& Levin, 1999). Second, we aim to address the "family innovation dilemma" (Duran et al., 2015), theorizing on the role of collaborations in reconciling the gap between innovation input and output in family firms, and between "what we know" and "what we need to know". In doing so, we will not only advance current understanding of how family firms use collaborations to 
innovate, but will also provide a new, integrative standpoint for studying family firm innovation from a broader and more coherent perspective.

\section{REVIEW SCOPE AND METHOD}

To provide an overview of existing research, we started searching for published articles on inter-firm collaborations in relation to innovation using the Scopus database in a systematic way. First, we determined the combinations of two sets of keywords: (1) alliance, collaboration, cooperation, coordination, partnership; and (2) R\&D, innovation, internationalization, globalization. Second, we conducted the search with the above combination of keywords in titles, keywords, and/or abstract. Our review of the collaborative innovation literature from the general management field was intended to develop a guiding framework to be used for the subsequent review in the family business field, therefore we only included collaborative innovation articles with sound theoretical perspective(s) from the leading management journals ${ }^{1}$. As existing literature is vast, we limit the scope of review to inter-firm relationship with the intention to access resources in achieving innovation. Overall, we found 58 articles: 44 quantitative, 3 qualitative, 5 mixed methods, and 6 conceptual/review articles.

Next, the first author read each article in detail, constructed a table tabulating the type of study, research question(s), research gap(s), theoretical perspective(s), focus of collaborations, study context, sample(s) used (type of data, source of data, time span, country and industry), constructs, level of analysis, and key findings of each article. With this process, we noticed emerging themes and patterns, leading us to the use of thematic analysis to further examine the articles (Boyatzis 1998). We used mind mapping method to map out the emerging themes and patterns, based on types of collaborations, functions of

\footnotetext{
${ }^{1}$ An appendix organizing selected studies on collaborative innovation as emerged from our review of the general management literature has been omitted from the manuscript for space reasons but is available from the authors upon request.
} 
collaborations, theoretical perspectives, research questions, constructs, study context, and key findings. During this process, we developed codes based on the emerging themes and patterns in terms of research questions asked, the theoretical perspectives used, and the outcome examined in these studies. When disagreement arose among the authors, we discussed until agreement was found. This process led us to identify three main perspectives: strategic, transactional, and relational. These perspectives are defined more clearly below.

First, starting from viewing collaborative innovation through the lens of the RBV, collaborations are used by firms as a means of strategic move in accessing the resources needed, leading to the outcome of knowledge transfer in achieving innovation. We code this stream as strategic view as it incorporates the use of collaborative innovation in tackling resource constraints. Second, we noted a stream of literature analyzing possible opportunistic behaviors by collaborating partners on the basis of game theory and the transaction cost economics (TCE). The governance mechanisms chosen to curb perceived opportunistic behaviors in collaborative innovation relationships are found to have effects on performance at both firm and collaboration levels. We code this stream as transactional view. Lastly, we observed a stream of literature that studies collaborative innovation using social theory, emphasizing the social exchange relations between partnering firms in a collaborative relationship. These social relationships emerge as crucial to the firms' willingness to collaborate and share knowledge, and are thus central to building collaborative innovation networks. We code this stream as relational view.

By organizing the literature into the three perspectives, we provide a systematic overview and understanding of the relationships among major constructs and theoretical perspectives. The organization of literature into these three perspectives reconciles the discontentment by researchers on the claim that one theory prevails another. For example, Yasuda (2005) argues that the use of RBV better explains the motivations for firms to form 
collaborative innovation. Gulati (1995) claims that the use of TCE views collaboration relationships as transactions and overlooks the trust built over ongoing relationships. Put simply, instead of arguing for the prevalence of one theory over another, we offer a holistic understanding of the construct measurement leading to outcomes. For example, under the strategic view, RBV points the need for resources as the antecedents of forming collaborative innovation (Eisenhardt \& Schoonhoven (1996), while the TCE approach in the transactional view analyzes whether the benefits of collaborative innovation outweigh the consequences (Parkhe, 1993). The relational view, based on social theory, provides understanding of the evolvement of collaborative relationship (Gulati, 1998). These three perspectives are not mutually exclusive; rather, they serve as a guiding framework to understand the relationship between key constructs and outcomes.

In the second stage of our literature review, we focused on building a robust and systematic literature review on collaborative innovation in family firms. To do so, we searched the published articles on collaborations in family firms in relation to innovation using the Scopus database (De Massis et al., 2013). In order to be inclusive of all literature covered on this topic, we allowed the span of studies going forward and backward in time with no constraints. We used combinations of three sets of keywords by combining keywords related to family business (family business, family firm, family management, family enterprise, family control, family ownership, family involvement, family governance, and family influence) with either (1) alliance, cooperation, collaboration, and partnership, or (2) open innovation, innovation, $\mathrm{R} \& \mathrm{D}$, internationalization, and network. Consistent with our focus on the topic of collaborative innovation in family firms, our selection process only includes articles that look at internationalization and network as a means to achieve innovation where such channels are used for accessing the resources needed, such as technology and know-how. For example, we included studies on internationalization 
conducted for the purpose of acquiring knowledge and network leading to access of resources that ultimately enable innovation.

Based on the criteria described above, we identified a total of 37 journal publications for the purpose of our review, including 31 empirical studies and 6 conceptual/review studies. To be more comprehensive in our review efforts, we examined the list of family business books reviewed by De Massis and Kotlar (2015) and examined the Google Books and US Library of Congress database by using the same keywords. Finally, we searched conference papers in the Scopus database with the same keywords in order to be inclusive on the latest debates. This process further yielded two book chapters, three books, and three conference proceedings, thus bringing the total number of materials for review to 45 . For the purpose of a robust review, these extra materials are not included in the table but add on to our review to provide further evidence of the importance of collaborative innovation in family firms. To create an organizing template to systematically review existing research on the topic of collaborative innovation in family firms, we analyzed each study in-depth, going through the research gaps, research questions, theories, assumptions, arguments, sample, data used, and findings.

\section{THREE PERSPECTIVES ON COLLABORATIVE INNOVATION}

Collaborative innovation refers to voluntary agreements among independent firms, involving exchange and sharing of resources such as capital, information, knowledge, and technology to achieve a common innovation goal (Das \& Teng, 2000; Gulati, 1995; Kale \& Singh, 2009; Un et al., 2010). We conceive such inter-firm relationships as temporary agreements with a specified time frame, on the basis of exchange and sharing, involving only partial internalization as the resources are still owned by the respective owner. Thus, we exclude mergers and acquisitions from our focus (Kale \& Singh, 2009). 
In achieving innovation, including product, process, and technological innovation, firms search for sources of inputs (Dosi, 1988). Leaning on Resource Dependence Theory (RDT) (Pfeffer \& Salancik, 1978), we content that no firm can be entirely self-sufficient in terms of resources needed in achieving innovation. The need for resources leads firms to access and exchange resources through collaborations as a strategic tool with external organizations. However, interdependence between organizations does not necessarily imply symmetric use and control of the resources (Pfeffer \& Salancik, 1978), thus pointing to the importance of governance structure in managing collaborations in deterring opportunistic behavior, and ultimately achieving the intended innovation goal. Nor does the interdependence dictate which organization a focal firm chooses to partner with. As firms engage in the interdependence relationship, network and trust influence the choice of the collaboration partner during the selection process, and in turn such relationship evolves over time.

Literature on collaborative innovation is vast, incorporating a wide range of theories from different schools of thought, and spreading across different types of industries and countries. We limit our review scope to collaborations specified as collaborative relationship with external organizations in relation to innovation. The three major perspectives identified in our review (i.e., strategic, transactional, and relational) are illustrated in Figure 1, along with their underlying theoretical perspectives, study contexts, key constructs, and outcomes of interest.

\section{Insert Figure 1 about here}

We organized our review around these perspectives as each involves a consistent pattern of constructs and relationships in the general management literature. The strategic view on collaborations builds on the foundations of resource based view (RBV) (Penrose, 1995; Wernerfelt, 1984) and competitive advantage (Barney, 1991), and focuses on how 
firms rely on access and recombination of external sources of resources to achieve innovation. The transactional view on collaborations builds on TCE (Williamson, 1979, 1981) and game theory, and focuses on assessing the different modes of governance structure in curbing possible opportunistic behaviors by partner organizations that would have an impact on the intended innovation goal. The relational view of collaboration builds on network (Burt, 1987, 1997) and trust evolved over time (Zaheer et al., 1998), and focuses on the implications of network and trust.

Although we identified a pattern of theories used according to the study context, there are some overlaps among theories used in some studies. However, we focus on the key constructs and relationships in each perspective to provide a coherent overview. The strategic view focuses on the use of collaborations as strategic means to access different sources of resources, the importance of absorptive capacity, knowledge transfer between firms at the collaboration level, and the effect of external factors such as institutional structure on formation of collaborative innovation and knowledge transfer. The transactional view focuses on performance implication from collaborative innovation, governance mode, opportunistic behavior, and partner diversity. The relational view focuses on the network point of view and how different relational aspects influence willingness to collaborate/share, trust, and partner selection.

\section{Strategic View on Collaborative Innovation}

Firms need various resources as inputs for innovation, and those resources need to be valuable, rare, inimitable, and non-substitutable (VRIN) in order to create sustained competitive advantages (Barney, 1991). Firms search first internally to recognize the resources they possess in relation to their competitive stance in the environment, and the resources needed to gain that competitive advantage. In achieving innovation, firms constantly search for inputs needed, including but not limited to capital, information, 
knowledge, and technology. As pointed out by RDT (Pfeffer \& Salancik, 1978), no firm is self-sufficient for all inputs needed in attaining innovation. Thus, in search of inputs, firms seek inputs from outside firms through collaborations in various forms, such as vertical and horizontal collaborations.

Early empirical work using RBV as a basis to examine collaboration (Eisenhardt \& Schoonhoven, 1996) points out how strategic position in the competitive market and innovation strategies drove firms to form alliances. In contrast with expectation, growth-stage firms have the lowest rate of collaboration. This is possibly due to the fact that they yet to have the capability to innovate and at the same time lack resources to lure collaborative partners. Although the work of Eisenhardt and Schoonhoven (1996) has been seminal in researching collaborations using the RBV perspective, it covers only limited aspects of RBV. The later work by Ahuja (2000), drawing upon RBV and social network theory, sheds additional light on how different forms of firm resources affect the opportunity to form collaborations.

Das and Teng (2000) are the first to systematically examine collaborations using RBV and apply the RBV perspective in guiding future research. These authors argue that the RBV is suitable to examine collaborations because firms use collaborations as a means to gain access to valuable resources that other firms possess. In the study, they further propose that (1) the characteristics (VRIN) of the resources that firms possess lead to formation of collaborations with other organizations; (2) resource types possessed by the partnering firms, that are either property-based or knowledge-based, determine the structure of the collaboration; and (3) collaboration performance is related to resource alignment between the partnering firms. Comparing the predictive power of RBV and TCE, Yasuda (2005) finds that RBV is better suitable than TCE to explain collaborative activities between firms in hightechnologies industries. 
Combining RBV and organizational learning perspective, Hitt et al. (2000) find that collaborative partners are selected based on possibilities to access their resources and possibilities for organizational learning. Leaning on RBV and knowledge access theory, and using internationalization as the study context, prior research also suggests that accessing resources is a motivation for forming collaborations by small medium enterprises (SMEs) due to their resource limitation and the need for resources (De Mattos et al., 2013; Dickson et al., 2006; Lu \& Beamish, 2001; Narula, 2004; Ulubaşoğlu et al., 2009). In addition, Lu and Beamish (2006) show that the lifespan of an international joint venture may be decreased as the SME acquires host country knowledge from the partnering firm through collaboration. Also, different types of resources possessed by the partner firm would have different effect on the international collaboration's performance. Furthermore, as firms seek resources needed in forming collaborations, possession of resources such as in-house R\&D capability and technology may make a firm be seen as more attractive partner (De Mattos et al., 2013; Fontana et al., 2006). Acknowledging that firms form collaborations to gain access to resources, Vasudeva et al. (2012) further use institutional theory (DiMaggio \& Powell, 1983; Meyer \& Rowan, 1977) to argue that institutional structure would have an influence on knowledge transfer. A firm is able to extract more knowledge from the partner firm when the partner firm is from a more corporatist country.

Using Korean biotechnology SMEs as sample, Kang \& Park (2012) find that SMEs with international and domestic collaborations achieve more innovation than did their counterparts without the collaborations, supporting the notion that collaborations lead to access to resources needed for innovation. Wiklund and Shepherd (2009) find that the ability to recombine resources between partnering firms play an important role in bringing actual benefits from collaborations. In addition to recognizing the need to collaborate in order to gain access to resources, researchers have also underlined the importance of absorptive 
capacity within each firm to facilitate knowledge transfer between partnering firms (Chen, 2004; Faems et al., 2007; Hall \& Bagchi-Sen, 2007; Kumar \& Nti, 1998; Mention, 2011; Mowery et al.,1996). Focusing specifically on access to knowledge, Un et al. (2010) show the different impact of collaboration on innovativeness among different collaboration partners, namely, suppliers, universities, customers, and competitors. Other research uses a knowledge complimentary perspective to analyze the effect of collaboration on innovativeness (Fang, 2011).

Highly innovative firms continuously pursue innovation and thus may have more than one collaboration for different purposes. This then points to the need for building collaboration capability through collaboration experience to better manage collaborations for the best outcome to achieve innovation, which we categorize under strategic view (Kale et al., 2002). Sampson (2005) examines the topic using a learning curve and shows that prior experience with collaborations has implications on learning to manage collaborations. However, Hoang and Rothaermel (2005) find diminishing returns of the positive effect of general alliance experience on the likelihood of alliance success. Rothaermel and Deeds (2006) claim that collaboration management capability is key for high-tech ventures to achieve competitive advantage. In addition, firms must be aware of the risks that alliances pose if a firm forms more alliances than it can manage (Rothaermel \& Deeds, 2006).

In sum, under the strategic view collaboration is used as a means to access valuable resources that firms otherwise do not possess to achieve innovation. Under this perspective, scholars focus on the strategic actions that firms undertake in collaborative innovation, namely, recognizing the need to collaborate, search of resources, collaborations management capability, attractiveness of a firm as collaborative partner, transfer of knowledge between partnering firms, the importance of absorptive capacity in combining and assimilating resources, and the effects of external factors. 


\section{Transactional View on Collaborative Innovation}

TCE (Williamson, 1979, 1981) is initially designed to explain when transactions are internalized within a firm or left to the market, or how firms address "make" versus "buy" decisions. According to this perspective, firms wishing to attain innovation face the dilemma of whether to have full ownership of the resources needed to attain innovation or to share it with other firms (Hennart, 1991). At the same time, the TCE approach points out the bounded rationality and opportunism characterizing human nature in pursuing self-interest. In collaborative relationships, firms are incentivized to take advantage to maximize the value from the collaboration at the expense of partnering firm(s) (Hennart, 1991). Using game theory, Parkhe (1993) illustrates that opportunism situations in collaboration are isomorphic to the prisoner's dilemma, where each firm would like to have maximum payoff in pursuit of individual competitive advantage. Because each firm possesses valuable resource(s) that lure the partnering firm(s) in forming collaboration, concerns arise over the possible leakage of firm's core competency, such as knowledge and technology.

Asymmetric control and use of resources in collaborative relationships between firms lead to appropriability hazards and opportunistic behavior, hence firms need to design different governance structures to address these issues, depending on internal and external context. Going back to the make or buy debate, scholars aim to know whether collaborations lead to achieving the intended goal of innovation, some indicators include improved innovation and financial performance, both at firm and collaboration level.

Oxley (1997) is among the earlier scholars who systematically examined the appropriability hazards using TCE. She shows that the collaboration form, contractual or equity based, depends mainly on the attributes of the transaction nature of the collaboration rather than firm-level characteristics. Moreover, Robertson and Gatignon (1998) extend this view using the notion of asset specificity, showing that the decision to engage in 
collaborative innovation is influenced by product category-specific assets, technology uncertainty, the ability to measure innovation performance, and prior experience of successful collaboration. In their later work, Oxley and Sampson (2004) further examine the probability hazard associated with potential leakage of intellectual property (IP) and find that, when risk is high, firms protect themselves from possible knowledge leakage by replacing governance arrangements with limitations to the scope of the collaboration. Continuing on the concern over knowledge leakage in collaborative innovation, Li et al. (2008) find that, depending on the appropriation risk, firms use partner selection, governance structure, and alliance scope as substitute mechanisms for protection.

Studies under the transactional view suggest that factors both at the firm and the collaboration level influence the effects of collaborations. Using financial measures, Kalaignanam et al. (2007) find that when a collaboration is formed between firms with different sizes, both large and small firms can benefit. Analyzing the relationship between age and alliance performance, Deeds and Rothaermel (2003) find a U-shaped curve, such that performance of collaborations first declines and then increases as the collaboration relationship ages. At the collaboration level, Parkhe (1993) finds that governance mode is related to collaboration performance, where perceived potential opportunism influences both governance mode and performance. The asymmetry of information between collaboration partners makes them wary of potential knowledge leakages. With governance structures in place, the perceived risk is reduced and thus firms are able to better achieve joint goals.

In achieving innovation, firms may have more than one single collaboration formed for different innovative projects. With the increased number of collaborations that a firm forms, managing collaborations is more than just a matter of curbing opportunisms, but also involves increased costs in managing the collaborations. Kale \& Singh (2009) introduce an alliance portfolio approach to better examine the benefit of collaborations on innovativeness 
and financial performance. In this regard, Lahiri \& Narayanan (2013) examine the relationship between alliance portfolio size, innovation, and financial performance. Their findings show that highly innovative firms benefit less from increasing alliance portfolio size than less innovative firms. In relation to internationalization, Lavie and Miller (2008) suggest that when firms expand their portfolio of collaborations internationally, they face the challenges in managing the increasing degree of foreignness that comes with cross-national differences among firms. Their results suggest that although firms' financial performance decreased initially with the internationalization of the alliance portfolio, the liability of foreignness can be overcome with accumulation of experience. This research also points to the need to set up organizational routines to manage foreign partners. Sampling on both domestic and international collaborations, Duysters and Lokshin (2011) find an inverted Ushaped relationship between alliance portfolio complexity and innovation performance.

In sum, under the transactional view we see how firms face appropriability hazard and opportunism in collaborative innovation due to asymmetry of information and control/use of resources, affecting performance at different levels. Under this stream of research, we focus on firm performance, innovation performance, collaboration performance, governance mode, coordination costs, organizational routines, opportunistic behavior, and partner diversity.

\section{Relational View on Collaborative Innovation}

Using social theory, Granovetter (1985) argues that the economy is made up of social relations between firms and trust is developed through repeated transactions rather than institutional arrangements. From the social network point of view, inter-firm relationships are not limited to transactions, but also involve continuous exchange of tangible and intangible resources within the embedded network over a specified period of time (Uzzi, 1997). Once a collaborative relationship is formed, for example to co-develop a new product, firms engage in a process that involves the exchange of ideas, knowledge, know-how, technology, and 
resources. As firms have limited knowledge about other organizations, they gather information about potential partners through the network. Therefore, social capital is contingent to firms in search of the right partner who possess complementary assets within the network where they can obtain information about the potential partner (Burt, 1997, 2004).

Gulati (1995) is the first to begin examining the governance mode of collaborations using social theory. He initially criticized the TCE view of collaborations as independent transactions and emphasized the importance of prior interactions between the collaboration partners. Although the findings support the TCE claim that firms use equity-based collaboration to curb possible opportunistic behavior, they also point to the need to further examine the role of trust that is formed through repeated formation of collaborations. In his later work, Gulati (1998) proposes to examine several aspects of collaborations using the social network perspective. In particular, under the relational view we focus on three research questions: (1) how do firms select partners to form collaborations; (2) how do prior ties and familiarity influence this choice; and (3) how do collaborative relationships evolve over time.

As suggested by the strategic view, recognition of the need for resources happens within the firm, as firms assess internally the resources needed to achieve innovation. However, the relational view suggests that the opportunities to form collaborations lie outside the firm (Ahuja, 2000; Eisenhardt \& Schoonhoven, 1996). In his study, Ahuja (2000) finds a positive relationship between formation of collaborations and social capital: the more linkages a firm possesses in prior industry network, the more technical collaborations are formed. Familiarity is increased through prior ties as firms acquire more information through direct or indirect contacts, thereby increasing the likelihood of forming a collaboration (Reuer \& Lahiri, 2014; Vanhaverbeke et al., 2002). Direct contacts come from formal transactions and indirect contacts come from network. 
In addition to assessing resources, firms need to attract collaborative partners in order to form collaborative relationships, which can be attained through building a social status (Stuart, 2000). Using high-technology industry as sample, Stuart (2000) shows if a firm wishes to upgrade its reputation through collaboration, with whom the focal firm partner with is more important than just the ability to form collaboration. This research suggests that a firm benefits from collaborations even if the ultimate goal is not achieved, because then the focal firm's reputation in the network is upgraded from surviving the due diligence of partner firm. This is especially the case when the partner firm is more reputable in the industry and more technologically sophisticated.

More recent work by Soh (2010) examines the implications of network centrality and finds that firms that position themselves centrally in the collaborative network achieve higher innovation outputs. In particular, the more centrally a firm is positioned in the collaborative network, the better its access to network resources such as information and opportunities. Continuing on the benefits of collaborative network, Fernhaber and Li (2013) find that international exposure through collaborative networking enhances the opportunities for internationalization. Firms become more willing to share knowledge as trust bred through prior ties (Gulati, 1995). As the willingness to share knowledge increases, the gap in knowledge asymmetry becomes lower, facilitating achievement of joint goals in collaborative innovation (Kim \& Song, 2007; Tiwana, 2008).

Familiarity increases through direct contact from prior ties or indirect contact through the network, thus building trust and increasing the willingness to both form collaborative innovation and share resources (Gulati, 1998). Using the relational perspective, we view collaborations as involving continuous exchange of resources and interactions over time. Thus, we focus on building the collaborative network that provides firms with more information, opportunities, and resources. 


\section{The Case for Studying Collaborative Innovation in Family Firms}

In the previous sections, we have outlined three distinct research perspectives within existing literature on collaborative innovation: the strategic, transactional, and relational views. Using these three perspectives as a guiding framework, we review research on collaborative innovation in family business. Several scholars have emphasized the heightened importance of and unique challenges associated with collaborative innovation in family firms. In order to innovate, family firms need to be entrepreneurial and take risks. These priorities are particularly important for family firms to survive in the highly dynamic and competitive markets and to achieve their long-term vision (James, 1999). Furthermore, strategic entrepreneurship also points to the importance of collaborative network, providing access to resources that firms need for innovation (Hitt et al., 2001). Yet, due to the unique characteristics of family firms, such as the unification of ownership and control, governance structure, family involvement and long-term vision, family firms behave differently from nonfamily firms (Chrisman et al., 2012; Chua et al., 1999; Mazzelli et al., 2017; Sharma et al., 2012). Within the family firm, family members work together, forming the corporate entrepreneurship ability to innovate and accomplish the family oriented vision (Sharma \& Chrisman, 1999). Thus, family firms would have different concerns and considerations in forming collaborative innovation with external organizations.

Existing research has shown that family firms prefer a lower level of R\&D investments compared to nonfamily firms. Despite this, they are still able to innovate (Block, 2012; Duran et al., 2015). The RDT prediction that no firm is self-sufficient for all the resources needed for innovation (Pfeffer \& Salancik, 1978) points to the need to further investigate how family firms access external resources needed for innovation. Despite the call for more in-depth understanding of collaborative innovation in family firms (De Massis et al., 2013), knowledge on this topic remains limited and fragmented. 


\section{OVERVIEW OF PRIOR RESEARCH ON COLLABORATIVE INNOVATION IN FAMILY FIRMS}

In this section, we discuss prior research on collaborative innovation in family firms, examine the samples used, theoretical perspectives/key constructs, focus of collaborations, and key findings/conclusions. We outline these articles in Table 1.

\section{Insert Table 1 about here}

\section{Methodological, Empirical, and Theoretical Issues}

Our analysis of 37 journal publications on collaborations in family firms shows that existing research ranges from micro factors such as family involvement (Nieto et al., 2015; Pittino et al., 2013) to macro factors like network (Anderson et al., 2005; Carney, 2005; Gurrieri, 2008; Kontinen \& Ojala, 2011; Li et al., 2015; Miller et al., 2009; Zahra, 2010; Zamudio et al., 2014), samples include small-to-medium enterprises (SMEs) (e.g., Alberti et al., 2014; Classen et al., 2012; Yeoh, 2014), private firms (e.g., Gurrieri, 2008; Miller et al., 2009; Sorenson et al., 2008), and publicly listed firms (e.g., Singh \& Gaur, 2013; Tsao \& Lien, 2013), across different industries including both primary and secondary data. With the distinct characteristics of family firms, some studies incorporate theoretical perspectives such as agency theory, behavioral theory, socioemotional wealth (SEW), and social capital to explain the relationship between unique family firm characteristics and collaborative innovation.

Of the 37 published articles reviewed, the studies with empirical data are quite evenly distributed between studying only family firms or comparisons of family firms versus nonfamily firms. The studies are also quite evenly distributed between primary and secondary data. In terms of geographical coverage, the studies cover a wide range of regions: Asia (Carney, 2005), Austria (Hatak \& Hyslop, 2015), Belgium and Netherlands (Classen et al., 2012), China (Deng et al., 2013; Li et al., 2015), Emerging markets (Kim et al., 2004), across 
EU countries (Broekaert et al., 2016), Finland (Kontinen \& Ojala, 2011; Kraus et al., 2012), France (Sirmon et al., 2008), Germany (Block \& Spiegel, 2013; Harms et al., 2015), India (Pant \& Rajadhyaksha, 1996; Singh \& Gaur, 2013), Italy (Alberti et al., 2014; Cassia et al., 2012; Denicolai et al., 2015; Gurrieri, 2008; Pittino \& Visintin, 2011; Pittino et al., 2013), Korea (Miller et al., 2009), Malaysia (Yeoh, 2014), Scotland (Anderson et al., 2005), Spain (Gómez-Mejía et al., 2007; Hausman, 2005; Nieto et al., 2015; Serrano-Bedia et al., 2016; Pérez, 2007), Taiwan (Tsao \& Lien, 2013), and US (Hausman, 2005; Sorenson et al., 2008; Spriggs et al., 2012; Stanley \& McDowell, 2014; Zahra, 2010).

With the nature of the topic on collaborative innovation, the sample firms in the studies include brewery, electronic and electrical industry, mid-high tech industry, manufacturing industry, SMEs, small firms, and tourism and hospitality. Some studies focus on family influence and external relationships without specifying any particular industry. Unlike the more mature field of general management with sound theoretical perspectives studying various causal relationships, the studies in the family business field use a broad range of theoretical perspectives and constructs in examining the relationship between unique family firm characteristics and various types of collaborative innovation.

As specified in the previous section, we included all studies where collaboration with external organizations is formed in order to innovate. Therefore, reviewed articles include studies on collaborations such as open innovation, external ties, cooperation, network, internationalization for the purpose of accessing resources, cooperative agreements, JVs, alliances, licensing agreements, business groups, and partnership.

\section{EXAMINING COLLABORATIVE INNOVATION IN FAMILY FIRMS}

As reported in our review of collaborative innovation in general management and family business literatures, while the topic has been well studied in the general management 
field with theoretically sound assumptions and clear measurements, current knowledge on collaborative innovation remains quite fragmented in the family business field.

In this section, we examine what we know and what we do not know about collaborative innovation in family firms. The extant literature on collaborative innovation from general management has not specifically considered the unique characteristics of family firms that are likely to play a role in inter-firm collaborations. For instance, Pant and Rajadhyaksha (1996) point out that, when forming collaborations with a family firm, the firm should pay attention to the unique characteristics of family firms including succession planning, authority structure, and centralized decision-making. In the last decades, family firm characteristics have been well studied in broad context and wide geographical span (Sharma et al., 2012). Therefore, we will not delve deep into the family firm characteristics themselves. Instead, we incorporate major constructs and relationships detected from our review of the general management field and take into account the influence of family firm characteristics on each construct at different levels of analysis, to identify research gaps for future research (Figure 2). We use grey boxes to indicate constructs that have been studied previously in the family business literature.

\section{Insert Figure 2 about here}

\section{Strategic View of Collaborative Innovation in Family Firms}

Under the strategic view, we mainly focus on the antecedents to forming collaborative innovation for the purpose of accessing resources at the family firm level to attain knowledge transfer and ultimately achieve innovation. Despite existing research largely suggests a lower willingness to engage in collaborative innovation among family firms, evidence of family firms relying on international alliances and $\mathrm{JVs}$ in order to acquire the resources in terms of knowledge, technology and financial capital that are needed for innovation is found in many countries around the world (Lubinski et al., 2013). Kim et al. (2004) find that, when facing 
competition from entry of foreign business, family conglomerates seek collaborations with foreign partners to obtain know-how and the latest technology. Focusing on family firms, Block and Spiegel (2013) find a positive relationship between family firm concentration and regional innovation output, where concentration of family firms in one region leads to better access to knowledge for innovation. Looking into the disappearance of Chinese family firms and their revival in the history, Li et al. (2015) emphasize the need for family firms to expand beyond family-based networks into collaborations with external parties in order to access resources. A conference proceeding using Italian companies as sample also acknowledges that collaborations lead family firms to information acquisition and growth opportunity (Banno \& Trento, 2016).

In terms of using collaborations as a strategy to tackle the need for resources, Pittino et al. (2013) examine the innovation strategies adopted by family firms in accessing technology through technology alliances to pursue innovation. Looking into strategy implementation in family firms in achieving innovation, Denicolai et al. (2015) investigate the effect of entrepreneur(s)' specific characteristics on implementation of collaborative innovation strategy through internationalization. Yeoh (2014) finds that external CEOs' international experience has positive effect on sourcing external technology, thus family firms can use hiring of external CEO as a strategy to access external technology.

Before diving into how and when family firms use collaborative innovation as a strategy to innovate, researchers should first explore the antecedents at firm level that lead family firms to form collaborative innovation. As pointed out in the existing literature, any firm starts by looking internally at the resources possessed and by assessing the resources needed to achieve innovation in order to remain competitive in the market. However, family firms are characterized by distinctive features such as risk aversion and unwillingness to 
relinquish control, which leads them to behave differently from their nonfamily counterparts (Chrisman et al., 2012; Chua et al., 1999; Kotlar \& De Massis, 2013; De Massis et al., 2014).

The question of how and when family firms assess the need to form collaborative innovation has been sparingly researched in empirical studies, with scholars emphasizing the effects of entrepreneurs' characteristics on innovation and internationalization (Denicolai et al., 2015), the effect of generation and composition of management team (Pittino et al., 2013), and the effect of external CEO (Yeoh, 2014). Nevertheless, this topic remains largely unexplored. Researchers may explore factors such as the aspiration level of the family firm to remain competitive, long-term orientation to survive the fierce market competition, familycentered non-economic goals to keep the family together, or SEW in keeping the family legacy (Berrone et al., 2012; Chrisman et al., 2012; Kotlar et al., 2014, 2017).

The only study we found that addresses family firm reaction to resource constraints is the book chapter by Grozdanić \& Radović-Marković (2015). Using a sample of family SMEs in Serbia, the study shows that the perceived resource constraints in terms of finance, labor, and new technology lead to the use of internationalization as a means to access the resources needed by family firms. With just one study available, we still know little about the antecedents that lead family firms to form collaborative innovation. While nonfamily firms generally have professional corporate governance structures in place and board of directors making strategic decisions, family firms have to constantly perform a balancing act between the firm and the family needs.

Yeoh (2014) suggests that family firms hire external CEOs with international experience to rely on their network as a strategy to obtain external technology. Existing research has outlined location (Block \& Spiegel 2013), expanding network beyond familybased network (Li et al., 2015) and group affiliation (Singh \& Gaur, 2013) as possible strategies to form collaborative innovation. Given the unique family firm characteristics, 
future research may look into the need to collaborate as an enabling factor to form collaborative innovation strategies.

Research Gap S1: How and when do family firms' need to collaborate and family goals influence the decision to collaborate and the collaboration strategy?

Having conceptualized collaborative innovation as a means to gain access to the resources needed for innovation, the next topic is family firms' absorptive capacity to assimilate and recombine knowledge in collaborative innovation. Drawing on a sample of private family SMEs in China, Deng et al. (2013) examine the effect of family ownership and control on innovation activities such as investment in $\mathrm{R} \& \mathrm{D}$, human capital, and location to access external resources for product innovation. Part of the study by Gurrieri (2008) examines the influence of entrepreneur's characteristics on firm absorptive capacity in relation to obtaining knowledge from the network. Drawing on a sample of emerging market firms in India, Singh and Gaur (2013) find a positive effect of family ownership and group affiliation on R\&D intensity and new foreign investments. Sirmon et al. (2008) illustrate the effect of family influence on $R \& D$ investment and on adopting internationalization in order to access knowledge in response to competitive thread of imitation.

Family firms need to invest in absorptive capacity in order to extract the benefit from collaborative innovation and attract collaboration partners. Although Gurrieri (2008) has examined the influence of entrepreneur's characteristics on family firm's absorptive capacity in extracting knowledge from the network, we still do not have an overall picture of other factors affecting absorptive capacity as family firms have many other concerns that reside in the need of the family. Thus, it is worth investigating the decision to form collaborative innovation as a determinant of investments in absorptive capacity. Drawing on RBV, Sirmon \& Hitt (2003) argue that the uniqueness of family firms enables them to possess unique resources that differentiate them from nonfamily firms, namely, human capital, social capital, patient financial capital, survivability capital, and governance structure. Therefore, future 
research could explore the mechanisms through which family firms' resource endowments lead to building absorptive capacity.

Taking into account a number of unique family firm characteristics, Roessl (2005) explores the tendencies and capabilities of family firms in forming collaborations. He argues that although family firms have certain characteristics that may hinder the willingness to collaborate, they do possess capabilities that would enhance their collaboration capability. For instance, long-term orientation, organizational slack, family decision-making, and communication skills are all aspects that may have an effect on collaboration capability. Although Roessl (2005) points out that family firms possess unique capabilities that would enhance their collaboration capability, we still lack empirical evidence examining family firms' collaboration capability. For example, the general management literature emphasizes the critical role of organizational learning in collaborative innovation (Sampson, 2005). Future research could examine how family involvement and family firm characteristics, such as centralized decision-making and family goals, influence such learning and collaboration capabilities.

Given family firms' unique characteristics, such as unification of ownership and control, governance structure, and centralized decision-making, nonfamily firms may be hesitant to form collaborative relationships with family firms. However, researchers have also pointed out unique resources that family firms possess (Sirmon \& Hitt, 2003). Thus, future research could further examine the advantages and disadvantages of family firms in forming collaborative innovation and how family firms can leverage such advantages to build absorptive capacity and collaboration capability that would in turn increase a family firm's attractiveness as a collaboration partner.

Research Gap S2: How do individual family firm characteristics, absorptive capacity and collaboration capability influence family firms' attractiveness as collaboration partners? 
Moving to the collaborative innovation relationship level, we now focus on knowledge transfer between collaboration partners. Pérez (2007) uses a historical view of Spanish steel wire industry to show how family firms chose to collaborate among themselves for knowledge transfer to achieve innovation. Drawing on RBV, Sirmon \& Hitt (2003) argue that family firms possess unique capabilities that can better facilitate knowledge transfer in collaborative innovation compared to nonfamily firms.

Using Taiwanese public listed family firms, Tsao and Lien (2013) show that family managers are better in overcoming the negative effects of the increased complexity and uncertainty arising from collaborative innovation and in extracting the benefits from collaborative innovation in comparison to nonfamily firms. If family firms do in fact have unique resources and capabilities, future research could further examine how these unique resources and capabilities would enable family firms to differently overcome potential obstacles and extract knowledge from collaborative innovation.

Research Gap S3: How do individual family firm characteristics, absorptive capacity and collaboration capability influence knowledge transfer in collaborative innovation?

We finally examine the impact of an external factor, namely institutional structure. While the effects of institutional structure on collaborative innovation have been studied in the general management field, this factor remains largely unexplored in the family business literature. For example, Kang and Park (2012) find that support in the form of funding from the government has far-reaching impact on stimulating SMEs' internal R\&D investments and forming collaborations, and in turn, promotes innovation output at both firm and collaboration level. In terms of knowledge transfer, Vasudeva et al. (2012) argue that firms would extract more knowledge from collaborative innovation if the partner firm were from a more corporatist country.

In the case of family firms, Pérez (2007) shows that family firms collaborate with each other and are able to transfer knowledge among them despite adverse institutional 
conditions arising from the economic environment and government policies. Still, we know little about the effects of institutional structure on collaborative innovation formed by family firms and about whether family firms possess more resilience than their nonfamily counterparts towards institutional structure. Future research could investigate the role of government support and other institutional factors in affecting formation of collaborative innovation and knowledge transfer in the family business context.

Research Gap S4: How do institutional structures influence family firms' willingness and ability to form collaborative innovations and manage knowledge transfer?

\section{Transactional View of Collaborative Innovation in Family Firms}

In this section, we examine collaborative innovation in family firms from the transactional view, further clarifying the different constructs at different levels and how these attributes affect collaboration performance and ultimately affect performance at firm level. The assumptions in this stream of research are primarily based on TCE and focus on whether collaborative innovation will bring benefits to family firms in terms of financial and innovation performance. Put it differently, whether the benefits derived from collaborative innovation will outweigh or not the transaction costs of collaborations. Consistent with studies from general management, we build on game theory to examine the effects of perceived opportunistic behavior by collaboration partner(s) in choosing between different contractual forms of collaborative innovation by family firms, and in turn, affecting collaboration performance. Consequently, we draw on behavioral theory to examine the effect of family influence on partner diversity and the effect of partner diversity on other constructs. In addition, we examine the role of organizational routines in family firms and the effects of organizational routines on collaboration performance. Subsequently, we draw on agency theory and stewardship theory to further examine the effect of family influence on collaboration performance. 
We found no study on family firms' perceived opportunistic behavior in collaborative innovation. From the review of the general management literature, Parkhe (1993) finds that perceived opportunistic behavior by collaboration partner would affect collaboration performance, as the focal firm would limit the exchange of various resources that would in turn limit the innovation capability in collaborative innovation. Owing to the different priorities that reside in family firms, they would have different concerns over opportunistic behavior by collaboration partner and perceive opportunism differently compared to nonfamily firms.

In terms of governance modes used by family firms in collaborative innovation concerning possible IP leakage, we argue that how family firms choose the governance mode for collaborative innovation is deeply influenced by unique family firm characteristics. Carney (2005) argues that owner-managers have more liberty in the way they manage the external relationship(s) and are free to discriminate between different transactional modes. Thus, the author suggests that owner-managers tend to form preferential business relations with specific organizations and may act in an instrumental manner with collaboration partner(s) as their priority is to maximize personal wealth. Interestingly, using financial modeling, Chiesa (2005) argues that collaboration is more likely to be used by family firms where agency problem is less severe.

In forming collaborative innovation, firms are generally concerned about unintended IP leakage, thus the use of different contractual forms of collaborations, such as equity vs. non-equity, limits the scope of collaborative innovation to better protect IP owned (Li et al., 2008; Oxley, 1997; Oxley \& Sampson, 2004). As pointed out by Carney (2005), ownermanagers' priority is to maximize personal wealth and they have high degree of freedom in choosing between different contractual forms of collaborative innovation. As family firms have different priorities compared to nonfamily firms, they will likely have different concerns 
when forming collaborative innovation. Existing research on collaborative innovation in the general management literature has shown that different governance modes would affect collaboration performance, as governance modes bind the partner firms in the collaborative innovation relationship and limit the exchange of crucial IP for the purpose of protecting IP owned individually (Parkhe, 1993). Yet, we know little in the context of family firms.

Research Gap T1: How does perceived opportunistic behavior influence the choice of governance mechanisms in family firms' collaborative innovations, and how do the governance mechanisms chosen in turn affect collaborative innovation performance?

In terms of partner diversity, the study by Classen et al. (2012) points to family firms having lower partner diversity in collaborative innovation. Family firm characteristics and search breadth in relation to partner diversity in the context of collaborative innovation have been studied by scholars in the family business literature (Alberti et al., 2014; Classen et al., 2012). Sampling on family SMEs, studies have shown that family firms have a lower search breadth in scouting collaborative partners compared to nonfamily firms (Alberti et al., 2014; Classen et al., 2012). In relation to search breadth, Classen et al. (2012) also find that family firms use a less diversified set of collaboration partners to access resources for innovation compared to nonfamily SMEs. They suggest that family firms have a lower search breadth and a less diversified set of partners due to their lower willingness to collaborate.

Collaboration partner diversity is another sparingly researched topic in family business literature. To our best knowledge, only Classen et al. (2012) have examined the diversity of collaboration partners used by family firms in accessing resources for innovation. Although the study has attributed the lower diversity of partners used by family firms to lower willingness to collaborate, little is known about the effect of family influence on partner diversity. We cannot conclude that family firms have lower partner diversity with the support of just one study.

It can be argued that the more diversified partners a family firm has, the more knowledge is obtained by the family firm. However, the relationship between partner 
diversity and innovation performance is not always linear (Duysters \& Lokshin, 2011). The higher is partner diversity, the more divided become the resources owned by the family firm as such resources are spread across different collaborations. Moreover, the effect of partner diversity on collaboration performance can be detrimental when the family firm has reached its capacity in managing various collaboration relationships.

Organizational routines have not been studied in family business literature in the context of collaborative innovation. Continuing on the topic of partner diversity, Lavie and Milller (2008) have pointed out the need for firms to set up organizational routines in managing a diversified set of collaborative innovation. There is scant research about organizational routines in family firms and no study in the context of collaborative innovation.

Research Gap T2: How do organizational routines influence family firms' ability to deal with partner diversity in collaborative innovation?

Lastly, we examine the effect of collaborative innovation on performance. Differently from the general management literature that studied the relationship between collaborative innovation and performance, in the family business literature family firm characteristics play a major role in various aspects. A conference proceeding explores family management and collaborations as one of the antecedents of family firm performance (Brenes et al., 2015). Integrating the family variable into the equation of collaborative innovation and performance, Tsao and Lien (Tsao \& Lien, 2013) find that family management and ownership positively moderate the innovation and performance implications of internationalization. On the other hand, the study by Serrano-Bedia et al. (2016) finds that family involvement determines higher transaction costs in collaborations, as family involvement has a negative moderating effect on the relationship between use of knowledge from collaboration and innovation performance. While Sorenson et al. (2008) find that collaborative network orientation (CNO) is positively associated with innovativeness and firm performance in family firms, the study 
by Spriggs et al. (2012) finds no support to the notion that CNO moderates the relationship between innovative capacity and firm performance. Drawing on a sample of family and nonfamily firms working as suppliers for universities in the US, Stanley and McDowell (2014) find a positive relationship between interorganizational trust and performance in both family and nonfamily firms.

Family firm performance in the context of collaborative innovation has been studied sparingly in the family business literature. Moreover, the findings are still fuzzy with inconsistent measurements, thus not able to provide insights on the effect of collaborative innovation on family firm performance. While the studies by Deng et al., (2013) and Tsao \& Lien, (2013) have specifically measured family firm innovativeness as a result of collaborative innovation, other studies measure family firm performance with different measures. For example, Sorenson et al. (2008) measure firm performance with five items covering aspects such as profit, growth and market share against major competitors. Spriggs et al. (2012) use seven items covering aspects like profit, growth and market share against competitor and industry, and Stanley \& McDowell (2014) use seven items to assess buyer satisfaction as indicator of firm performance as a supplier. To our best knowledge, the only study that distinguishes between financial performance and innovation performance is the one by Tsao \& Lien (2013). We propose that future research should measure family firm innovativeness and financial performance separately. For example, higher financial performance can possibly lead to higher family firm capability to innovate and higher innovation capability can eventually lead to higher profits. With these two firm-level attributes clearly defined and measured, we can then examine the effectiveness of collaborative innovation on family firm performance.

The implication of collaborative innovation at the collaboration level has not been studied in the family business literature. In particular, virtually no study has focused on the 
outputs of collaborative innovation at the collaboration level, such as joint patents or new products.

Research Gap T3: How does collaborative innovation influence innovation and financial performance in family firms?

\section{Relational View of Collaborative Innovation in Family Firms}

Finally, we examine the studies on collaborative innovation in family firms under the relational view, based on social exchange and network theories, to further examine the role of network and trust in the case of family firms, ultimately leading to willingness to collaborate and share. Network possessed by family firms has been well studied, thus we focus on the effects of network and how family firms utilize network to form collaborative innovation. We examine the external partner level, prior ties and familiarity, and their effects on network and trust at the relationship level. At the family firm level, we examine family firms' willingness to collaborate and share as well as the effect of network and trust on their willingness.

Looking at interactions with external partner firms, research from general management has shown that familiarity increases through prior ties and repeated transactions, and in turn concurs to build trust (Gulati, 1995). Prior ties include direct interactions through formal contractual ties and indirect interactions through informal means such as network. Familiarity, such as knowing the operational style of a firm or traditional ways of doing business by a firm, increases with repeated interactions as firms get to know more about one another. As family firms are long-term oriented, they tend to be community oriented and invest in social capital in building long-lasting relationships with external parties (Miller \& Le Breton-Miller, 2005). A book chapter by Schumann (1999) illustrates how German family firms formed their own network among entrepreneurial family firms through the social ties they possess or through marriage. The network formed by these German family firms is so significant that it is able to exert political influences, substituting business trade association 
during the industrialization era. The study by Carrasco-Hermandez and Jimenez-Jimenez (2013) finds that the network possessed by family firms has a positive influence on innovation. This points to the need to further examine the role of prior ties and familiarity in the family business context, which will likely have implications on network and trust at collaboration level, as we will discuss further in the following sections.

Family firms are believed to possess strong social capital derived from strong ties that lie in family relations. Zamudio et al. (2014) argue that there is need to further examine network and social capital in the family business field: how do family firms collaborate with external firms and generate competitive advantage? Indeed, several studies have illustrated the benefits of the network possessed by family firms (Anderson et al., 2005; Li et al., 2015; Miller et al., 2009). Drawing on a sample of Scottish family firms, Anderson et al. (2005) find that family members who do not work for the family firm continue to provide help and assistance in an instrumental and functional way that is close to that of business ties, where such support is of high quality and at low or non-existent cost. Given their cultural background, Chinese family firms possess unique network, as they tend to form strong ties with family, relatives, and friends, as well as using marriage as a means to secure or maintain ties in building a supportive network (Li et al., 2015). Sampling on Korean firms, Miller et al. (2009) find that investments in community and connection are indeed germane to success to emerging market and high technology industry. Additional insights from a study using Spanish family firms also supports the notion that family firms build collaborative network through their strong social capital, eventually leading to innovation (Carrasco-Hernández \& Jiménez-Jiménez, 2013).

Research Gap R1: How do prior ties influence family firm's ability to build trust and networks in collaborative innovations?

Partner selection for collaborative innovation is another important, yet underresearched topic. To date, we have identified only one study by Harms et al. (2015) exploring 
family firms' propensity towards partner selection for collaborations. Sampling on tourism and hospitality sector in Germany, Harms et al. (2015) find that family firms favored formal cooperation predominantly with non-competitors. While nonfamily firms choose collaboration partners among friends, acquaintances or strangers (Li et al., 2008), family firms have the additional option of choosing from network and prior ties formed through family ties. In addition, due to the unification of ownership and control in family firms, the decision on partner selection would be deeply influenced by the owning family.

In contrast to the transactional view according to which family firms have lower search breadth and less diversified collaboration partners, Carney (2005) argues that ownermanagers have more liberty in choosing the contractual relations and thus are better able to generate a more diversified network of relations comprising diversified business partners. Further dissecting network owned by family firms into formal and informal ties, Kontinen and Ojala (2011) find that family SMEs mainly recognize international opportunities by establishing new formal ties, while informal ties and family ties have a less significant role. Aside from looking at network formed by family firm's informal ties, Gurrieri (2008) points out the influence of entrepreneur's characteristics on network creation. If family firms possess a wide range of network, how do family firms form collaborations with external organizations through their network and social capital (Zamudio et al., 2014)?

Research Gap R2: How does the network possessed by a family firm influence partner selection in forming collaborative innovation?

The ability and willingness paradox in family firm innovation argues that although family firms have superior ability to innovate, they are less willing to do so (Chrisman et al., 2015). In this section, we examine studies in relation to family firms' willingness to collaborate. Based on a multiple case study on Italian firms, Cassia et al., (2012) find that family firms are less willing to collaborate and share in comparison to nonfamily firms, and this in turn hampers innovation performance. Using 54-years data from Spanish family firms 
in olive oil mills, Gomez-Mejia et al. (2007) shows how family firms' willingness to collaborate varies in relation to economic prospects and perceived threats to SEW. Looking into the innovation behavior, Nieto et al. (2015) find that family influence has a negative effect on willingness to collaborate and family firms are significantly less prone to engage in technological collaborations. Pittino and Visintin (2011) find that family firms are less willing to collaborate compared to nonfamily firms, though generation effect and succession plan are found to affect family firms' propensity of to collaborate. Prior research from general management has shown that familiarity and prior ties increase the probability and willingness of collaboration formation (Reuer \& Lahiri, 2014; Vanhaverbeke et al., 2002). However, these streams of research have yet to consider family firm variables. Therefore, future research could further examine whether the network possessed by family firms and trust increase family firms' willingness to form collaborative innovation.

Research Gap R3: How do network and trust influence family firms' willingness to engage in collaborative innovation?

Looking from the relational view, little is known about the factors affecting family firms' willingness to share resources. Network as one of the knowledge sources for family firms has been addressed in the book by Del Giudice et al., (2010), who identify knowledge sharing as a critical success for higher innovation output. Using a case study of a dyadic collaboration between two family firms in Austria, Hatak and Hyslop (2015) find that trust enables family firms' willingness to share and eliminates the need for formalized contracts. In the same case study, both family business owners grew up in the same region in Austria and belong to the same network of friends, which also provides evidence on the role of prior ties and familiarity in building trust in family firms.

Firms engaged in collaborative innovation are likely to share their resources to achieve the common innovation goal. Family firms, given their unique characteristics and long-standing legacy, may have different concerns compared to nonfamily firms in sharing 
resources such as know-how and technology. Gulati (1995) finds that firms are more willing to share knowledge with trust breed through prior ties. Moreover, Gulati (1995) has shown that the more the transactions among partnering firms are repeated over time, the less likely is the subsequent collaboration to be equity based. Given the unique characteristics of family firms, trust can be built differently in family firms and in turn have varying effects in comparison to nonfamily firms. Nevertheless, the role of trust and how it is developed by family firms in collaborative innovation from the perspective of the relational view has only been sparingly explored through a single case study by Hatak and Hyslop (2015).

Future research could look into the role of trust and network in deterring concerns arising from family influence in relation to knowledge sharing. Furthermore, future research could look into the temporal dimension, incorporating unique family firm characteristics to shed further insights into the trust that is built over time in relation to forming collaborative innovation by family firms. Ideally, such studies should be longitudinal.

Research Gap R4: How do network and trust influence family firms' willingness to share knowledge and resources in collaborative innovation?

\section{CONCLUSION}

Family firms are ubiquitous and play a crucial role across all world economies (La Porta et al., 1999), hence the relevance of investigating collaborative innovation in family firms. However, given their unique characteristics, family firms behave differently from nonfamily firms, and this leads to strong conceptual reasons why their collaborative innovation behavior is likely to be distinct at many levels.

We started by proposing external sources of innovation as a key aspect to address the family innovation dilemma, according to which family firms tend to invest less in R\&D and are yet able to innovate more compared to their nonfamily counterparts. Based on this contention, we first reviewed the literature on collaborative innovation in the general 
management field and outlined a guiding framework for our subsequent analysis of collaborative innovation in the family business field. We then organized the studies on collaborative innovation in family business according to three main perspectives: strategic, transactional, and relational, each outlining constructs at focal firm level, collaboration relationship level involving firms engaged in the collaborative innovation, and external level dealing with partner organization(s) and external factors. This was done by examining the research questions, study contexts, theoretical assumptions, relationship between each constructs, and findings. Overall, this article attempts to enhance current understanding of past literature on collaborative innovation by bridging the general management and family business research streams, developing a framework that combines the literatures from both fields and helps identify research gaps in current knowledge about collaborative innovation in family firms. Interestingly, there are recent articles that appear to take on our research agenda and thus support our claims regarding the need for further research along the directions previously outlined. For instance, Lambrecht et al. (2017), through a multiple case study on four family SMEs, explore how family SMEs operating in low- and medium-technology industries can successfully engage in open innovation by managing multiple and conflicting goals within the family business in distinctive ways and by taking up orchestration roles within their own open innovation networks to minimize the concern for the loss of control. Likewise, Casprini et al. (2017) start addressing one of the gaps that we examined above (i.e., RG S3) by highlighting, through a single case study of an Italian family firm, how this family firm managed to overcome the barriers to the acquisition and transfer of knowledge in open innovation processes.

Given the many constructs and relationships that might affect collaborative innovation in family firms, we have only started to scratch the surface of the issues that need to be investigated. For instance, going beyond firm boundary, future research on collaborative 
innovation in family firms could explore the use of family conglomerates to gain access to resources and yet retain ownership and control. In this business structure, it is a matter of looking into collaborative innovation in business families. The business subsidiaries collaborate with one another as stand alone businesses and yet are controlled by one or more enterprising business families. Thus, the concept of "boundary", that is crucial to identify the external parties involved in collaborative innovation, may vary depending on whether we are referring to a family business or an enterprising business family governing a number of businesses with a portfolio logic, and the implications of such differences are yet to be unearthed. Nevertheless, it is our hope that this review article and the research gaps that we identified will stimulate and guide future academic work in this promising research avenue, with important implications for both the family business and the general management research streams.

\section{REFERENCES}

Ahuja, G. (2000). The duality of collaboration: Inducements and opportunities in the formation of interfirm linkages. Strategic Management Journal, 21(3), 317-343.

Alberti, F. G., Ferrario, S., Papa, F., \& Pizzurno, E. (2014). Search breadth, open innovation and family firms: evidences in Italian mid-high tech SMEs. International Journal of Technology Intelligence and Planning, 10(1), 29.

Anderson, A. R., Jack, S. L., \& Dodd, S. D. (2005). The role of family memeber in entrepreneurial networks: Beyond the boundaries of the family firm. Family Business Review, $18(2), 135-154$.

Arregle, J. L., Hitt, M. A., Sirmon, D. G., \& Very, P. (2007). The development of organizational social capital: attributes of family firms. Journal of Management Studies, 44(1), 73-106.

Bannò, M., \& Trento, S. (2016, April). Italian Family Firms Internationalization: An Empirical Analysis. In ICMLG2016-4th International Conference on Management, Leadership and Governance: ICMLG2016 (p. 25). Academic Conferences and publishing limited.

Barney, J. (1991). Firm resources and sustained competitive advantage. Journal of Management, 17(1), 99-120.

Berrone, P., Cruz, C., \& Gomez-Mejia, L. R. (2012). Socioemotional wealth in family firms: Theoretical dimensions, assessment approaches, and agenda for future research. Family Business Review, 25(3), 258-279.

Block, J. H. (2012). R\&D investments in family and founder firms: An agency perspective. Journal of Business Venturing, 27(2), 248-265.

Block, J. H., \& Spiegel, F. (2013). Family firm density and regional innovation output: An exploratory analysis. Journal of Family Business Strategy, 4(4), 270-280. 
Boyatzis, R. E. (1998). Transforming qualitative information: Thematic analysis and code development. Sage.

Brenes, E. R., Ciravegna, L., \& Pichardo, C. A. (2015, January). Family Business, Institution Voids and Performance in Emerging Markets. In Academy of Management Proceedings (Vol. 2015, No. 1, p. 10015). Academy of Management.

Broekaert, W., Andries, P., \& Debackere, K. (2016). Innovation processes in family firms: the relevance of organizational flexibility. Small Business Economics, 47(3), 771-785.

Burt, R. (1987). Social Contagion and Innovation: Cohesion Versus Structural Equivalence. American Journal of Sociology, 92(6), 1287-1335.

Burt, R. (1997). The Contingent Value of Social Capital. Administrative Science Quarterly, 42, $339-365$.

Burt, R. (2004). Structural holes and good ideas. American Journal of Sociology, 110(2).

Carney, M. (2005). Globalization and the renewal of Asian business networks. Asia Pacific Journal of Management, 22(4), 337-354.

Carrasco-Hernández, A., \& Jiménez-Jiménez, D. (2013). Can family firms innovate? Sharing internal knowledge from a social capital perspective. Electronic Journal of Knowledge Management, 11(1), 30-37.

Casprini E., De Massis A., Di Minin A., Frattini F., \& Piccaluga A. (2017). How family firms execute open innovation strategies: The Loccioni case. Journal of Knowledge Management. In press.

Cassia, L., De Massis, A., \& Pizzurno, E. (2012). Strategic innovation and new product development in family firms: An empirically grounded theoretical framework. International Journal of Entrepreneurial Behavior \& Research, 18(2), 198-232.

Chen, C.-J. (2004). The effects of knowledge attribute, alliance characteristics, and absorptive capacity on knowledge transfer performance. $R$ and D Management, 34, 311-321.

Chen, H.-L., \& Hsu, W.-T. (2009). Family Ownership, Board Independence, and R\&D Investment. Family Business Review, 22(4), 347-362.

Chesbrough, H. W. (2006). Open Innovaion: The New Imperative for Creating and Profiting from Technology. Harvard Business Press.

Chiesa, G. (2005). Information sharing and optimum financing mode. The Manchester School, 73(1), 50-74.

Chrisman, J. J., Chua, J. H., De Massis, A., Frattini, F., \& Wright, M. (2015). The ability and willingness paradox in family firm innovation. Journal of Product Innovation Management, $32(3), 310-318$.

Chrisman, J. J., Chua, J. H., Pearson, A. W., \& Barnett, T. (2012). Family Involvement, Family Influence, and Family-Centered Non-Economic Goals in Small Firms. Entrepreneurship: Theory and Practice, 36, 267-293.

Chrisman, J. J., \& Patel, P. C. (2012). Variations in R\&D Investments of Family and Nonfamily Firms: Behavioral Agency and Myopic Loss Aversion Perspectives. Academy of Management Journal, 55(4), 976-997.

Chua, J. H., Chrisman, J. J., \& Sharma, P. (1999). Defining the Family Business by Behavior. Entrepreneurship Theory and Practice, 23, 19-40.

Classen, N., Gils, A., Bammens, Y., \& Carree, M. (2012). Accessing Resourcses from Innovation Partnrs: The Search Breadth of Family SMEs. Journall Od Small Business Management, 50(2), 191-215.

Czarnitzki, D., \& Kraft, K. (2009). Capital control, debt financing and innovative activity. Journal of Economic Behavior and Organization, 71(2), 372-383.

Das, T. K., \& Teng, B.-S. (2000). A Resource-Based Theory of Strategic Alliances. Journal of Management, 26(1), 31-61.

De Massis, A., Audretsch, D., Uhlaner, L., \& Kammerlander, N. (2017). Innovation with limited 
resources: Management lessons from the German Mittelstand. Journal of Product Innovation Management, In press. DOI: 10.1111/jpim.12373.

De Massis, A., Frattini, F., \& Lichtenthaler, U. (2013). Research on Technological Innovation in Family Firms: Present Debates and Future Directions. Family Business Review, 26(1), 10-31.

De Massis, A., \& Kotlar, J. (2015). Learning Resources for Family Business Education : A Review and Directions for Future Developments. Academy of Management Learning \& Education, 14(3), 415-422.

De Massis A., Kotlar J., Chua J.H., \& Chrisman J.J. (2014). Ability and willingness as sufficiency conditions for family-oriented particularistic behavior: Implications for theory and empirical Studies. Journal of Small Business Management, 52(2), 344-364.

De Mattos, C., Burgess, T. F., \& Shaw, N. E. (2013). The impact of R\&D-specific factors on the attractiveness of small- and medium-sized enterprises as partners vis-a-vis alliance formation in large emerging economies. $R$ and D Management, 43(1), 1-20.

Deeds, D. L., \& Rothaermel, F. T. (2003). Honeymoons and Liabilities: The Relationship between Age and Performance in Research and Development Alliances. Journal of Product Innovation Management, 20(404), 468-484.

Del Giudice, M., Della Peruta, M. R., \& Carayannis, E. G. (2010). Knowledge and the family business: the governance and management of family firms in the new knowledge economy. Springer Science \& Business Media.

Deng, Z., Hofman, P. S., \& Newman, A. (2013). Ownership concentration and product innovation in Chinese private SMEs. Asia Pacific Journal of Management, 30(3), 717-734.

Denicolai, S., Hagen, B., \& Pisoni, A. (2015). Be international or be innovative? Be both? The role of the entrepreneurial profile. Journal of International Entrepreneurship, 13(4), 390-417.

Dickson, P. H., Weaver, K. M., \& Hoy, F. (2006). Opportunism in the R\&D alliances of SMES: The roles of the institutional environment and SME size. Journal of Business Venturing, 21(4), 487-513.

DiMaggio, P., \& Powell, W. (1983). The iron cage revisited: Institutional isomorphism and collective rationality in organizational fields. American Sociological Review, 48(2), 147-160.

Dosi, G. (1988). Sources , Procedures, and Microeconomic Effects of Innovation. Journal of Economic Literature, 26(3), 1120-1171.

Duran, P., Kammerlander, N., Essen, M. van, \& Zellweger, T. (2015). Doing more with less: Innovation input and output in family firms. Academy of Management Journal, In-press.

Duysters, G., \& Lokshin, B. (2011). Determinants of alliance portfolio complexity and its effect on innovative performance of companies. Journal of Product Innovation Management, 28(4), $570-585$.

Eisenhardt, K. M., \& Schoonhoven, C. B. (1996). Resource-based View of Strategic Alliance Formation: Strategic and Social Effects in Entrepreneurial Firms. Organization Science, 7(2).

Faems, D., Janssens, M., \& Looy, B. Van. (2007). The Initiation and Evolution of Interfirm Knowledge Transfer in R\&D Relationships. Organization Science, 28(11), 1699-1728.

Fang, E. (2011). The Effect of Strategic Alliance Knowledge Complementarity on New Product Innovativeness in China. Organization Science, 22(1), 158-172.

Fernhaber, S. a., \& Li, D. (2013). International exposure through network relationships: Implications for new venture internationalization. Journal of Business Venturing, 28(2), 316334.

Fontana, R., Geuna, A., \& Matt, M. (2006). Factors affecting university-industry R and D projects: The importance of searching, screening and signalling. Research Policy, 35(2), 309323.

Gómez-Mejía, L. R., Takács Haynes, K., Núñez-Nickel, M., Jacobson, K. J. L., \& MoyanoFuentas, J. (2007). Socioemotional Wealth and Business Risks in Family-controlled Firms: Evidence from Spanish Olive Oil Mills. Administrative Science Quarterly, 52, 106-137. 
Granovetter, M. (1985). Economic action and social structure: the problem of embeddedness. American Journal of Sociology, 91(3), 481-510.

Grozdanić, R., \& Radović-Marković, M. (2015). Family businesses motives for internationalisation: Evidence from Serbia. In Family Businesses in Transition Economies. Springer International Publishing.

Gulati, R. (1995). Does Familiarity Breed Trust? the Implications of Repeated Ties for Contractual Choice in Alliances. Academy of Management Journal, 38(1), 85-112.

Gulati, R. (1998). Alliances and Networks. Strategic Management Journal, 19, 293-317.

Gurrieri, A. R. (2008). Knowledge network dissemination in a family-firm sector. Journal of Socio-Economics, 37(6), 2380-2389.

Hall, L. a., \& Bagchi-Sen, S. (2007). An analysis of firm-level innovation strategies in the US biotechnology industry. Technovation, 27(1-2), 4-14.

Harms, H., Memili, E., \& Steeger, J. (2015). Expert insights on the determinants of cooperation in family firms in tourism and hospitality sector. Journal of Co-Operative Organization and Management, 3(2), 72-83.

Hatak, I., \& Hyslop, K. (2015). Cooperation between family businesses of different size: A case study. Journal of co-operative organization and management, 3(2), 52-59.

Hausman, A. (2005). Innovativeness among small businesses: Theory and propositions for future research. Industrial Marketing Management, 34(8), 773-782.

Hennart, J. (1991). The Transaction Costs Theory of Joint Ventures: An Empirical Study of Japanese Subsidiaries in the United States. Management Science, 37(4), 483-497.

Hirsch, P. M., \& Levin, D. Z. (1999). Umbrella Advocates Versus Validity Police: A Life-Cycle Model. Organization Science, 10(2), 199-212.

Hitt, M. a., Dacin, M. T., Levitas, E., Arregle, J. L., \& Borza, a. (2000). Partner selection in a merging and developed market context: Resource-based and organizational learning perspectives. Academy of Management Journal, 43(3), 449-467.

Hitt, M. a., Ireland, R. D., Camp, S. M., \& Sexton, D. L. (2001). Strategic entrepreneurship: entrepreneurial strategies for wealth creation. Strategic Management Journal, 22(6-7).

Hoang, H., \& Rothaermel, F. T. (2005). The effect of general and partner-specific alliance experience on joint R\&D project performance. Academy of Management Journal, 48(2), 332345.

James, H. S. (Jr). (1999). Owner as Manager: Extended Horizons and the Family Firm. International Journal of the Economics of Business, 6(1), 41-55.

Kalaignanam, K., Shankar, V., \& Varadarajan, R. (2007). Asymmetric New Product Development Alliances: Win-Win or Win-Lose Partnerships? Management Science, 53(3), 357-374.

Kale, P., Dyer, J. H., \& Singh, H. (2002). Alliance capability, stock market response, and longterm alliance success: the role of the alliance function. Strategic Management Journal, 23(8), 747-767.

Kale, P., \& Singh, H. (2009). Managing strategic alliances: What do we know now, and where do we go from here? Academy of Management Perspectives, 23(3), 45-62.

Kang, K. N., \& Park, H. (2012). Influence of government R\&D support and inter-firm collaborations on innovation in Korean biotechnology SMEs. Technovation, 32(1), 68-78.

Keil, T., Maula, M., Schildt, H., \& Zahra, S. A. (2008). The effect of governance modes and relatedness of external business development activities on innovative performance. Strategic Management Journal, 29(8), 895-907.

Kellermanns, F. W., \& Hoy, F. (Eds.). (2016). The Routledge Companion to Family Business. Routledge.

Kim, C., \& Song, J. (2007). Creating new technology through alliances: An empirical investigation of joint patents. Technovation, 27(8), 461-470. 
Kim, D., Kandemir, D., \& Cavusgil, S. T. (2004). The Role of Family Conglomerates in Emerging Markets: What Western Companies Should Know. Thunderbird International Business Review, 46(517), 13-38.

Konig, A., Kammerlander, N., \& Enders, A. (2013). The family innovator's dilemma: How family influence affects the adoption of discontinuous technologies by incumbent firms. Academy of Management Review, 38(3), 418-441.

Kontinen, T., \& Ojala, A. (2011). International Opportunity Recognition among. Journal of Small Business Management, 49(3), 490-514.

Kotlar, J., \& De Massis, A. (2013). Goal setting in family firms: Goal diversity, social interactions, and collective commitment to family-centered goals. Entrepreneurship: Theory and Practice, 37(6), 1263-1288.

Kotlar, J., De Massis, A., Frattini, F., Bianchi, M., \& Fang, H. (2013). Technology Acquisition in Family and Nonfamily Firms: A Longitudinal Analysis of Spanish Manufacturing Firms. Journal of Product Innovation Management, 30(6), 1073-1088.

Kotlar, J., Fang, H., De Massis, A., \& Frattini, F. (2014). Profitability Goals, Control Goals, and the R\&D Investment Decisions of Family and Nonfamily Firms. Journal of Product Innovation Management, 31(6), 1128-1145.

Kotlar, J., Signori, A., De Massis, A., \& Vismara, S. (2017). Financial wealth, socioemotional wealth and IPO underpricing in family firms: A two-stage gamble model. Academy of Management Journal. In press.

Kraus, S., Pohjola, M., \& Koponen, A. (2012). Innovation in family firms: an empirical analysis linking organizational and managerial innovation to corporate success. Review of Managerial Science, 6(3), 265-286.

Kumar, R., \& Nti, K. O. (1998). Differential Learning and Interaction in Alliance Dynamics: A Process and Outcome Discrepancy Model. Organization Science, 9(3), 356-367.

La Porta, R., Lopez-De-Silanes, F., \& Shleifer, A. (1999). Corporate ownership around the world. The Journal of Finance, 54(2).

Lahiri, N., \& Narayanan, S. (2013). Vertical integration, innovation, and alliance portfolio size: Implications for firm performance. Strategic Management Journal, 34(9), 1042-1064.

Lambrechts, F., Voordeckers, W., Roijakkers, N., \& Vanhaverbeke, W. (2017). Exploring open innovation in entrepreneurial private family firms in low- and medium-technology industries. Organizational Dynamics, http://dx.doi.org/10.1016/j.orgdyn.2017.05.001.

Lavie, D., \& Miller, S. R. (2008). Alliance Portfolio Internationalization and Firm Performance. Organization Science, 19(4), 623-646.

Li, D., Eden, L., Hitt, M., \& Ireland, D. (2008). Friends , Acquaintances or Strangers ? Partner Selection in R\&D Alliances. Academy of Management Journal, 51(2), 315-334.

Li, X. C., Chen, L., Chua, J. H., Kirkman, B. L., Rynes-Weller, S., \& Gomez-Mejia, L. (2015). Research on Chinese Family Businesses: Perspectives. Management and Organization Review, 11(4), 579-597.

Lu, J. W., \& Beamish, P. W. (2001). The internationalization and performance of SMEs. Strategic Management Journal, 22(6-7), 565-586. http://doi.org/10.1002/smj.184

Lu, J. W., \& Beamish, P. W. (2006). Partnering strategies and performance of SMEs' international joint ventures. Journal of Business Venturing, 21(4), 461-486.

Lubinski, C., Fear, J., \& Pérez, P. F. (2013). Family multinationals: entrepreneurship, governance, and pathways to internationalization (Vol. 23). Routledge.

Matzler, K., Veider, V., Hautz, J., \& Stadler, C. (2015). The impact of family ownership, management, and governance on innovation. Journal of Product Innovation Management, 32(3), 319-333.

Mazzelli, A., Kotlar,J., \& De Massis, A. (2017). Blending in while standing out: Selective conformity and new product introduction in family firms. Entrepreneurship Theory \& 
Practice, In press.

Mention, A. L. (2011). Co-operation and co-opetition as open innovation practices in the service sector: Which influence on innovation novelty? Technovation, 31(1), 44-53.

Meyer, J., \& Rowan, B. (1977). Institutionalized organizations: Formal structure as myth and ceremony. American Journal of Sociology, 83(2), 340-363.

Miller, D., \& Le Breton-Miller, I. (2005). Management Insights from Great and Struggling Family Businesses. Long Range Planning, 38(6), 517-530.

Miller, D., Lee, J., Chang, S., \& Breton-Miller, I. Le. (2009). Filling the institutional void: The social behavior and performance of family vs non-family technology firms in emerging markets. Journal of International Business Studies, 40(5), 802-817.

Mowery, D. C., Oxley, J. E., \& Silverman, B. S. (1996). Strategic Alliances and Interfirm Knowledge Transfer. Strategic Management Journal, 17(Winter Special Issue), 77-91.

Munari, F., Oriani, R., \& Sobrero, M. (2010). The effects of owner identity and external governance systems on R\&D investments: A study of western European firms. Research Policy, 39(8), 1093-1104.

Munoz-Bullon, F., \& Sanchez-Bueno, M. J. (2011). The impact of family involvement on the R\&D intensity of publicly traded firms. Family Business Review, 24(1), 62-70.

Narula, R. (2004). R\&D collaboration by SMEs: New opportunities and limitations in the face of globalisation. Technovation, 24(2), 153-161.

Nieto, M. J., Santamaria, L., \& Fernandez, Z. (2015). Understanding the Innovation Behavior of Family Firms. Journal of Small Business Management, 53(2), 382-399.

Oxley, J. E. (1997). Appropriability Hazards and Governance in Strategic Alliances : A Transaction Cost Approach. Journal of Law, Economics, and Organization, 13(2), 387-409.

Oxley, J. E., \& Sampson, R. C. (2004). The scope and governance of international R\&D alliances. Strategic Management Journal, 25(89), 723-749.

Pant, P. N., \& Rajadhyaksha, V. G. (1996). Partnership with an Asian family business - What every multinational corporation should know. Long Range Planning, 29(6), 812-820.

Parkhe, A. (1993). Strategic Alliance Structuring: A Game Theoretic and Transaction Cost Examination on Interfirm Cooperation. Academy of Management, 36(4), 794-829.

Penrose, E. T. (1995). The Theory of the Growth of the Firm. Oxford University Press.

Pérez, P. F. (2007). Small firms and networks in capital intensive industries: The case of Spanish steel wire manufacturing. Business History, 49(5), 647-667.

Pfeffer, J., \& Salancik, G. R. (1978). The External Control of Organizations A Resource Dependence Perspective. (R. E. Beach, Ed.). Harper \& Row Publisher.

Pittino, D., \& Visintin, F. (2011). The propensity toward inter-organizational cooperation in small- and medium-sized family businesses. Journal of Family Business Strategy, 2(2), 57-68.

Pittino, D., Visintin, F., Bau, M., \& Mazzurana, P. (2013). Collaborative technology strategies and innovation in family firms. International Journal of Entrepreneurship and Innovation Management, 17(1-3), 8-27.

Reuer, J. J., \& Lahiri, N. (2014). Searching for Alliance Partners: Effects of Geographic Distance on the Formation of R\&D Collaborations. Organization Science, 25(1), 283-298.

Robertson, T., \& Gatignon, H. (1998). Technology Development Mode: A transaction cost conceptualization. Strategic Management Journal, 19(6), 515-531.

Roessl, D. (2005). Family Businesses and Interfirm Cooperation. Family Business Review, 18(3), 203-214.

Rothaermel, F. T., \& Deeds, D. L. (2006). Alliance type, alliance experience and alliance management capability in high-technology ventures. Journal of Business Venturing, 21(4), 429-460.

Sampson, R. C. (2005). Experience effects and collaborative returns in R\&D alliances. Strategic Management Journal, 26(11), 1009-1031. 
Schilling, M. A. (2009). Understanding the alliance data. Strategic Management Journal, 30(3), 233-260.

Schumann, D. (1999). Buddenbrooks Revisited. In Authority and Control in Modern Industry: Theoretical and Empirical Perspectives. Routledge.

Serrano-Bedia, A. M., López-Fernández, M. C., \& Garcia-Piqueres, G. (2016). Analysis of the relationship between sources of knowledge and innovation performance in family firms. Innovation, 18(4), 489-512.

Sharma, P., \& Chrisman, J. J. (1999). Toward a Reconciliation of the Definitional Issues in the Field of Corporate Entrepreneurship. Entrepreneurship Theory and Practice, Spring, 11-27.

Sharma, P., Chrisman, J. J., \& Gersick, K. E. (2012). 25 Years of Family Business Review: Reflections on the Past and Perspectives for the Future. Family Business Review, 25(1), 5-15.

Singh, D. A., \& Gaur, A. S. (2013). Governance structure, innovation and internationalization: Evidence from India. Journal of International Management, 19(3), 300-309.

Singh, K., \& Mitchell, W. (2005). Growth dynamics: the bidirectional relationship between interfirm collaboration and business sales in entrant and incumbent alliances. Strategic Management Journal, 26(6), 497-521.

Sirmon, D. G., Arregle, J. L., Hitt, M. A., \& Webb, J. W. (2008). The role of family influence in firms' strategic responses to threat of imitation. Entrepreneurship: Theory and Practice, $32(6$ SPEC. ISS.), 979-998.

Sirmon, D. G., \& Hitt, M. A. (2003). Managing resources- Linking unique resources, management and wealth creation in Family Firms. Entrepreneurship: Theory and Practice, 27, 339-358.

Soh, P.-H. (2010). Network patterns and competitive advantage before the emergence of a dominant design. Strategic Management Journal, 31, 438-461.

Sorenson, R. L., Folker, C. A., \& Brigham, K. H. (2008). The Collaborative Network Orientation: Achieving Business Success through Collaborative Relationships. Entrepreneurship Theory and Practice, 32(4), 615-634.

Spriggs, M., Yu, A., Deeds, D., \& Sorenson, R. L. (2012). Too Many Cooks in the Kitchen: Innovative Capacity, Collaborative Network Orientation, and Performance in Small Family Businesses. Family Business Review, 26(1), 32-50.

Stanley, L. J., \& McDowell, W. (2014). The role of interorganizational trust and organizational efficacy in family and nonfamily firms. Journal of Family Business Strategy, 5(3), 264-275.

Stuart, T. E. (2000). Interorganizational Alliances and the Performance of Firms : a Study of Growth and Innovation Rates in a High- Technology Industry, 811(January 1998), 791-811.

Tiwana, A. (2008). Too much of a good thing? absorptive capacity, firm performance, and the moderating role of entrepreneurial orientation. Strategic Management Journal, 29, 251-272.

Tomlinson, P. R. (2010). Co-operative ties and innovation: Some new evidence for UK manufacturing. Research Policy, 39(6), 762-775.

Tsao, S. M., \& Lien, W. H. (2013). Family Management and Internationalization: The Impact on Firm Performance and Innovation. Management International Review, 53(2), 189-213.

Ulubaşoğlu, M. A., Akdiş, M., \& Kök, S. B. (2009). Internationalization and Alliance Formation Evidence from Turkish SMEs. International Small Business Journal, 27(3), 337-361.

Un, C. A., Cuervo-Cazurra, A., \& Asakawa, K. (2010). R\&D collaborations and product innovation. Journal of Product Innovation Management, 27(5), 673-689.

Uzzi, B. (1997). Social Structure and Competition in Interfirm Networks : The Paradox of Embeddedness. Administrative Science Quarterly, 42, 35-67.

Vanhaverbeke, W., Duysters, G., \& Noorderhaven, N. (2002). External Technology Sourcing Through Alliances or Acquisitions: An Analysis of the Application-Specific Integrated Circuits Industry. Organization Science, 13(6), 714-733.

Vasudeva, G., Spencer, J. W., \& Teegen, H. J. (2012). Bringing the Institutional Context Back In: 
A Cross-National Comparison of Alliance Partner Selection and Knowledge Acquisition. Organization Science, (March 2015). http://doi.org/10.1287/orsc.1120.0743

Vasudeva, G., Zaheer, A., \& Hernandez, E. (2013). The embeddedness of networks: Institutions, structural holes, and innovativeness in the fuel cell industry. Organization science, 24(3), 645663.

Wernerfelt, B. (1984). A Resource-based View of the Firm. Strategic Management Journal, 5(2), 171-180.

Wiklund, J., \& Shepherd, D. a. (2009). The Effectiveness of Alliances and Acquisitions: The Role of Resource Combination Activities. Entrepreneurship Theory and Practice, 33(315), 193-213.

Williamson, O. E. (1979). Transaction-Cost Economics : The Governance of Contractual Relations. Journal of Law and Economics, 22(2), 233-261.

Williamson, O.E. (1981). Economics of Organization: The Transaction Cost Approach. American Journal of Sociology, 87(3), 548-577.

Yasuda, H. (2005). Formation of strategic alliances in high-technology industries: Comparative study of the resource-based theory and the transaction-cost theory. Technovation, 25(7), 763770 .

Yeoh, P.-L. (2014). Internationalization and performance outcomes of entrepreneurial family SMEs: The role of outside CEOs, technology sourcing, and innovation. Thunderbird International Business Review, 56(1), 77-96.

Zaheer, A., McEvily, B., \& Perrone, V. (1998). Does Trust Matter? Exploring the Effects of Interorganizational and Interpersonal Trust on Performance. Organization Science, 9(2), 141159.

Zahra, S. A. (2010). Harvesting family firms' organizational social capital: A relational perspective. Journal of Management Studies, 47(2), 345-366.

Zamudio, C., Anokhin, S., \& Kellermanns, F. W. (2014). Network analysis: A concise review and suggestions for family business research. Journal of Family Business Strategy, 5(1), 6371.

Zeng, S. X., Xie, X. M., \& Tam, C. M. (2010). Relationship between cooperation networks and innovation performance of SMEs. Technovation, 30(3), 181-194. 
Figure 1. Three Streams of Perspectives on Collaborative Innovation

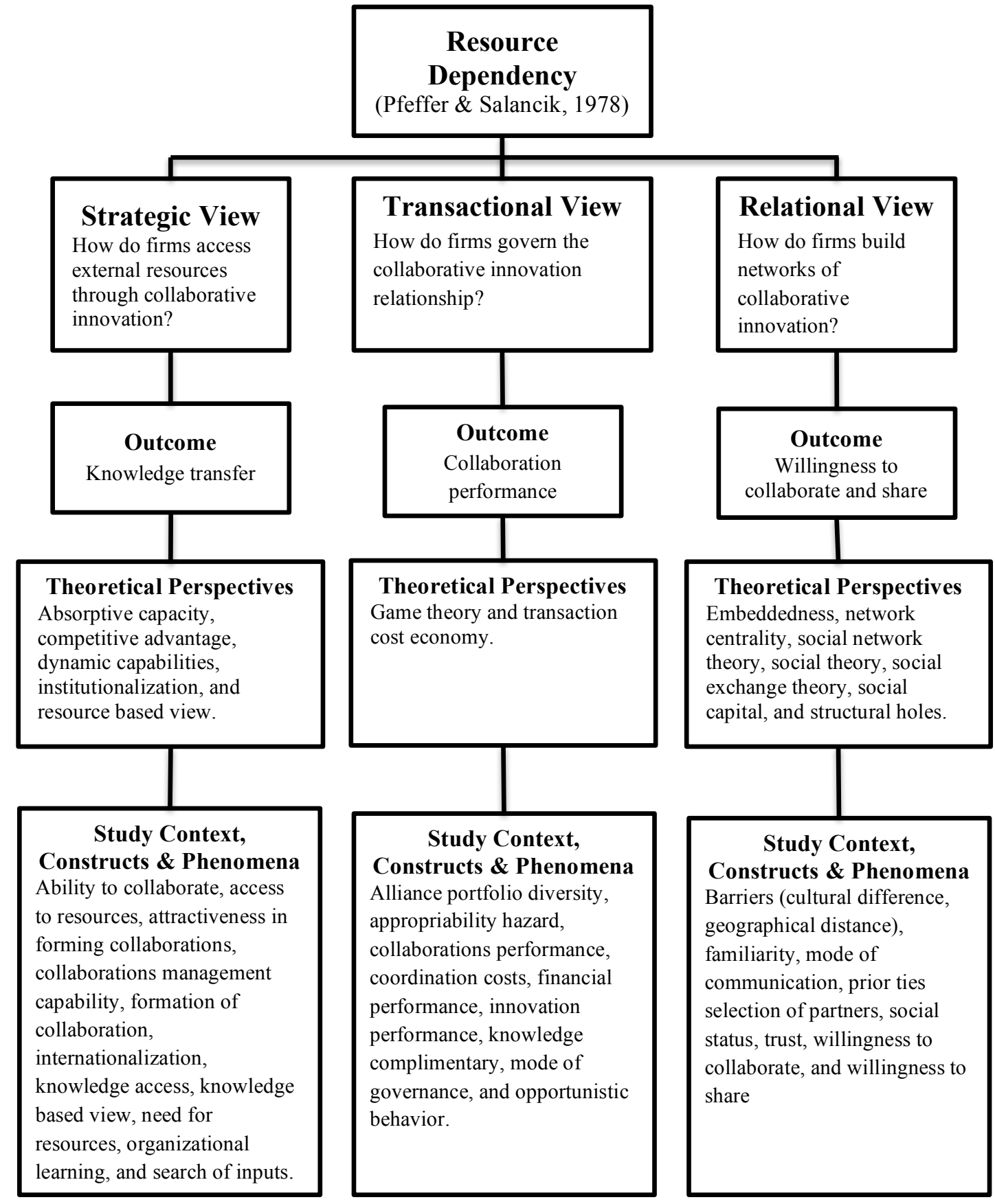


Table 1. Selected Studies on Collaborative Innovation in Family Firms

\begin{tabular}{|c|c|c|c|c|c|c|c|c|c|c|c|}
\hline No. & Authors & $\begin{array}{l}\text { Type of } \\
\text { Paper }\end{array}$ & $\begin{array}{c}\text { Sample } \\
\text { Description }\end{array}$ & Data & $\begin{array}{l}\text { Comp } \\
\text { arative } \\
\text { Study }\end{array}$ & $\begin{array}{l}\text { Theoretical } \\
\text { Perspective }\end{array}$ & $\begin{array}{l}\text { Focus of Alliance/ Collaboration/ } \\
\text { Cooperation }\end{array}$ & $\begin{array}{l}\text { Finding(s)/Conclusions(s) on } \\
\text { collaborative innovation }\end{array}$ & Strategic & Transactional & Relational \\
\hline 1 & $\begin{array}{l}\text { Alberti et } \\
\text { al. (2014) }\end{array}$ & $\begin{array}{l}\text { Empirical - } \\
\text { Quantitative }\end{array}$ & $\begin{array}{l}276 \\
\text { questionnaire } \\
\text { s, SMEs, } \\
\text { mid-high } \\
\text { tech, Italy }\end{array}$ & $\begin{array}{l}\text { Primary } \\
\text { data }\end{array}$ & $\begin{array}{l}\text { Family } \\
\text { versus } \\
\text { nonfam } \\
\text { ily } \\
\text { firms }\end{array}$ & $\begin{array}{l}\text { Behavioral } \\
\text { theory, open } \\
\text { innovation }\end{array}$ & $\begin{array}{l}\text { Open innovation - external } \\
\text { collaboration for innovation process. }\end{array}$ & $\begin{array}{l}\text { (Findings) Family firms have a } \\
\text { lower search breadth than } \\
\text { nonfamily firms. Generation } \\
\text { effect, presence of external } \\
\text { experts/scientists, practice to } \\
\text { consult external experts, and } \\
\text { willingness to shorten time of } \\
\text { innovation have varied impact on } \\
\text { search breadth. }\end{array}$ & N/A & N/A & $\begin{array}{l}\text { The effect of } \\
\text { family influence } \\
\text { on search breadth } \\
\text { affecting partner } \\
\text { diversity. }\end{array}$ \\
\hline 2 & $\begin{array}{l}\text { Anderson } \\
\text { et al. } \\
(2005)\end{array}$ & $\begin{array}{l}\text { Empirical - } \\
\text { Mixed } \\
\text { method }\end{array}$ & $\begin{array}{c}68 \\
\text { questionnaire } \\
\text { s, } 12 \\
\text { interviews, } \\
\text { Scotland }\end{array}$ & $\begin{array}{l}\text { Primary } \\
\text { data }\end{array}$ & $\begin{array}{l}\text { Only } \\
\text { family } \\
\text { firms }\end{array}$ & $\begin{array}{l}\text { Entrepreneuria } \\
1 \text { network }\end{array}$ & $\begin{array}{l}\text { Strong ties/embedded network - } \\
\text { personal and professional ties. }\end{array}$ & $\begin{array}{l}\text { (Findings) Family members who } \\
\text { do not work for the family firm } \\
\text { continue to provide help and } \\
\text { assistance in instrumental and } \\
\text { functional way that is close to that } \\
\text { of business ties, where such } \\
\text { support is of high quality and at } \\
\text { low or non-existent cost. }\end{array}$ & N/A & N/A & $\begin{array}{l}\text { The benefit of } \\
\text { network outside } \\
\text { family firms. }\end{array}$ \\
\hline 3 & $\begin{array}{l}\text { Block and } \\
\text { Spiegel } \\
(2013)\end{array}$ & $\begin{array}{l}\text { Empirical - } \\
\text { Quantitative }\end{array}$ & $\begin{array}{l}526 \mathrm{FFs} \text {, } \\
\text { Germany }\end{array}$ & $\begin{array}{l}\text { Seconda } \\
\text { ry data }\end{array}$ & $\begin{array}{l}\text { Only } \\
\text { family } \\
\text { firms }\end{array}$ & $\begin{array}{l}\text { Knowledge } \\
\text { spillover }\end{array}$ & $\begin{array}{l}\text { Cooperation with universities or } \\
\text { research institute, allowing access to } \\
\text { complementary technological } \\
\text { resources, faster development of } \\
\text { innovation, improved market access, } \\
\text { scale and scope economies, cost } \\
\text { sharing and risk reduction. }\end{array}$ & $\begin{array}{l}\text { (Findings) A positive relationship } \\
\text { is found between family firm } \\
\text { concentration and regional } \\
\text { innovation output. }\end{array}$ & $\begin{array}{l}\text { The effect of location } \\
\text { for access to } \\
\text { knowledge for } \\
\text { innovation. }\end{array}$ & $\mathrm{N} / \mathrm{A}$ & N/A \\
\hline 4 & $\begin{array}{l}\text { Broekaert } \\
\text { et al. } \\
(2016)\end{array}$ & $\begin{array}{l}\text { Empirical - } \\
\text { Quantitative }\end{array}$ & $\begin{array}{l}2604 \text { firms, } \\
\text { EU }\end{array}$ & $\begin{array}{l}\text { Seconda } \\
\text { ry data }\end{array}$ & $\begin{array}{l}\text { Family } \\
\text { versus } \\
\text { nonfam } \\
\text { ily } \\
\text { firms }\end{array}$ & $\begin{array}{l}\text { Competitive } \\
\text { advantage }\end{array}$ & $\begin{array}{l}\text { Collaborations with external partners } \\
\text { providing external ideas and stimulate } \\
\text { different types of innovation, such as } \\
\text { customers and suppliers for } \\
\text { incremental innovation, and } \\
\text { universities and research } \\
\text { organizations for radical innovation. }\end{array}$ & $\begin{array}{l}\text { (Findings) Family firms are found } \\
\text { to be more flexible than nonfamily } \\
\text { firms, thus able to manage external } \\
\text { relations better and achieve better } \\
\text { innovation performance. }\end{array}$ & $\begin{array}{l}\text { Organizational } \\
\text { flexibility as } \\
\text { collaboration } \\
\text { capability in family } \\
\text { firms in better } \\
\text { manage external } \\
\text { relations. } \\
\end{array}$ & $\mathrm{N} / \mathrm{A}$ & $\mathrm{N} / \mathrm{A}$ \\
\hline 5 & $\begin{array}{l}\text { Carrasco- } \\
\text { Hernandez } \\
\text { and } \\
\text { Jimenez- } \\
\text { Jimenez } \\
(2013)\end{array}$ & $\begin{array}{l}\text { Empirical - } \\
\text { Quantitative }\end{array}$ & $\begin{array}{l}282 \mathrm{FFs} \\
\text { Spain }\end{array}$ & $\begin{array}{l}\text { Primary } \\
\text { data }\end{array}$ & $\begin{array}{l}\text { Only } \\
\text { family } \\
\text { firms }\end{array}$ & Social Capital & $\begin{array}{l}\text { Network of inter-firm relationships } \\
\text { providing access to knowledge, } \\
\text { resources and technologies. }\end{array}$ & $\begin{array}{l}\text { (Findings) There is a positive } \\
\text { relationship between social capital } \\
\text { and innovation in family firms, } \\
\text { although familiness has a } \\
\text { moderating effect. }\end{array}$ & $\mathrm{N} / \mathrm{A}$ & N/A & $\begin{array}{l}\text { Capitalizing } \\
\text { family firms' } \\
\text { social capital. }\end{array}$ \\
\hline 6 & $\begin{array}{l}\text { Carney } \\
(2005)\end{array}$ & Review & Asia & - & - & $\begin{array}{l}\text { Agency } \\
\text { perspectives }\end{array}$ & Network of business partners. & $\begin{array}{l}\text { (Conclusions) Owner-managers } \\
\text { have greater liberty to utilize and } \\
\text { benefit from both arm's length and } \\
\text { relational contracting. Owner } \\
\text { managers are likely to generate } \\
\text { more diverse networks relations } \\
\text { comprised of different forms of } \\
\text { contracts.. }\end{array}$ & $\mathrm{N} / \mathrm{A}$ & $\begin{array}{l}\text { The effect of } \\
\text { owner manager } \\
\text { on managing } \\
\text { collaborations. }\end{array}$ & $\begin{array}{l}\text { The effect of } \\
\text { owner manager on } \\
\text { generating } \\
\text { networks. }\end{array}$ \\
\hline
\end{tabular}




\begin{tabular}{|c|c|c|c|c|c|c|c|c|c|c|c|}
\hline 7 & $\begin{array}{l}\text { Cassia et al. } \\
\quad(2012)\end{array}$ & $\begin{array}{l}\text { Empirical - } \\
\text { Qualitative }\end{array}$ & $\begin{array}{l}10 \text { firms, } \\
\text { Northern } \\
\text { Italy }\end{array}$ & $\begin{array}{l}\text { Primary } \\
\text { data }\end{array}$ & $\begin{array}{l}\text { Family } \\
\text { versus } \\
\text { nonfam } \\
\text { ily } \\
\text { firms } \\
\end{array}$ & - & $\begin{array}{l}\text { Collaboration with external parties for } \\
\text { new product development. }\end{array}$ & $\begin{array}{l}\text { (Findings) Family firms are found } \\
\text { to be less willing to collaborate } \\
\text { compared to nonfamily firms and } \\
\text { this has a negative effect on new } \\
\text { product development. }\end{array}$ & N/A & N/A & $\begin{array}{l}\text { The effect of } \\
\text { family variable on } \\
\text { the willingness to } \\
\text { collaborate and } \\
\text { share. }\end{array}$ \\
\hline 8 & $\begin{array}{l}\text { Classen et } \\
\text { al. }(2012)\end{array}$ & $\begin{array}{l}\text { Empirical - } \\
\text { Quantitative }\end{array}$ & $\begin{array}{l}167 \text { SMEs, } \\
\text { manufacturin } \\
\text { g industry, } \\
\text { Belgium \& } \\
\text { Netherlands }\end{array}$ & $\begin{array}{l}\text { Primary } \\
\text { data }\end{array}$ & $\begin{array}{l}\text { Family } \\
\text { versus } \\
\text { nonfam } \\
\text { ily } \\
\text { firms }\end{array}$ & $\begin{array}{l}\text { RBV, } \\
\text { behavioral } \\
\text { theory }\end{array}$ & $\begin{array}{l}\text { Collaboration with external firms for } \\
\text { innovation activities, such as } \\
\text { customers, suppliers, competitors, or } \\
\text { other organizations like research } \\
\text { institute or consultant. }\end{array}$ & $\begin{array}{l}\text { (Findings) Family SMEs have a } \\
\text { lower search breadth than } \\
\text { nonfamily SMEs. The search } \\
\text { breadth gap may be filled by } \\
\text { selecting either a better educated } \\
\text { family CEO or increase nonfamily } \\
\text { managers. }\end{array}$ & N/A & N/A & $\begin{array}{l}\text { The effect of } \\
\text { family influence } \\
\text { on the diversity of } \\
\text { partners. }\end{array}$ \\
\hline 9 & $\begin{array}{l}\text { Deng et al. } \\
\text { (2013) }\end{array}$ & $\begin{array}{l}\text { Empirical - } \\
\text { Quantitative }\end{array}$ & $\begin{array}{l}43,728 \\
\text { SMEs, } \\
\text { manufacturin } \\
\text { g firms, } \\
\text { China }\end{array}$ & $\begin{array}{l}\text { Seconda } \\
\text { ry data }\end{array}$ & $\begin{array}{l}\text { Family } \\
\text { versus } \\
\text { nonfam } \\
\text { ily } \\
\text { firms }\end{array}$ & Agency theory & Collaboration with external parties. & $\begin{array}{l}\text { (Findings) Investment in R\&D, } \\
\text { human capital, and location within } \\
\text { a special economic or } \\
\text { technological development zone } \\
\text { have a positive impact on product } \\
\text { innovation. }\end{array}$ & $\begin{array}{l}\text { The effect of family } \\
\text { ownership on } \\
\text { innovative activities. }\end{array}$ & N/A & N/A \\
\hline 10 & $\begin{array}{l}\text { Denicolai } \\
\text { et al. } \\
(2015)\end{array}$ & $\begin{array}{l}\text { Empirical - } \\
\text { Quantitative }\end{array}$ & $\begin{array}{l}302 \text { small } \\
\text { firms, Italy }\end{array}$ & $\begin{array}{l}\text { Primary } \\
\text { data }\end{array}$ & $\begin{array}{l}\text { Only } \\
\text { family } \\
\text { firms }\end{array}$ & $\begin{array}{l}\text { Upper echelon } \\
\text { (UE) } \\
\text { perspective }\end{array}$ & $\begin{array}{l}\text { Internationalization - entering new } \\
\text { market. }\end{array}$ & $\begin{array}{l}\text { (Findings) Firms based on } \\
\text { "family" characteristics are the } \\
\text { most limited in terms of innovation } \\
\text { and internationalization, while the } \\
\text { team-founded firms have the } \\
\text { widest set of innovation. }\end{array}$ & $\begin{array}{c}\text { The effects of } \\
\text { entrepreneur(s)' } \\
\text { characteristics on } \\
\text { strategy } \\
\text { implementation on } \\
\text { innovation and } \\
\text { internationalization. }\end{array}$ & N/A & N/A \\
\hline 11 & $\begin{array}{l}\text { Gomez- } \\
\text { Mejia et al. } \\
\text { (2007) }\end{array}$ & $\begin{array}{l}\text { Empirical - } \\
\text { Quantitative }\end{array}$ & $\begin{array}{l}1,237 \mathrm{FFs} \\
\text { Spain }\end{array}$ & $\begin{array}{l}\text { Seconda } \\
\text { ry data }\end{array}$ & $\begin{array}{l}\text { Only } \\
\text { family } \\
\text { firms }\end{array}$ & SEW & Part of a cooperative. & $\begin{array}{l}\text { (Findings) Willingness to } \\
\text { collaborate is related to economic } \\
\text { prospect as well as SEW. }\end{array}$ & N/A & N/A & $\begin{array}{l}\text { The willingness to } \\
\text { collaborate, using } \\
\text { SEW as reference } \\
\text { point. }\end{array}$ \\
\hline 12 & $\begin{array}{l}\text { Gurrieri } \\
(2008)\end{array}$ & $\begin{array}{l}\text { Empirical - } \\
\text { Quantitative }\end{array}$ & $\begin{array}{l}166 \mathrm{FFs}, \\
\text { Italy }\end{array}$ & $\begin{array}{l}\text { Primary } \\
\text { data }\end{array}$ & $\begin{array}{l}\text { Only } \\
\text { family } \\
\text { firms }\end{array}$ & Network & Relationship formed between firms. & $\begin{array}{l}\text { (Findings) Entrepreneur's } \\
\text { characteristics influence firm's } \\
\text { innovativeness, absorptive } \\
\text { capacity and social capital, } \\
\text { impacting the relationships in the } \\
\text { network. }\end{array}$ & $\begin{array}{l}\text { The effect of } \\
\text { absorptive capacity } \\
\text { on obtaining } \\
\text { knowledge from } \\
\text { network. }\end{array}$ & N/A & $\begin{array}{l}\text { The influence of } \\
\text { entrepreneur's } \\
\text { characteristics on } \\
\text { network creation. }\end{array}$ \\
\hline 13 & $\begin{array}{l}\text { Harms et } \\
\text { al. }(2015)\end{array}$ & $\begin{array}{l}\text { Empirical - } \\
\text { Quantitative }\end{array}$ & $\begin{array}{l}21 \text { surveys } \\
\text { and financial } \\
\text { data of } 1,488 \\
\text { firms, } \\
\text { tourism \& } \\
\text { hospitality, } \\
\text { Germany } \\
\end{array}$ & $\begin{array}{l}\text { Primary } \\
\text { +second } \\
\text { ary data }\end{array}$ & $\begin{array}{l}\text { Family } \\
\text { versus } \\
\text { nonfam } \\
\text { ily } \\
\text { firms }\end{array}$ & $\begin{array}{l}\text { Cooperative } \\
\text { behavior }\end{array}$ & $\begin{array}{l}\text { Formal and informal cooperative } \\
\text { agreements including competitors and } \\
\text { non-competitors. }\end{array}$ & $\begin{array}{l}\text { (Findings) Family firms favor } \\
\text { formal cooperation predominantly } \\
\text { with non-competitors. }\end{array}$ & N/A & N/A & $\begin{array}{l}\text { The effect of } \\
\text { family influence } \\
\text { on partner } \\
\text { selection. }\end{array}$ \\
\hline 14 & $\begin{array}{l}\text { Hatak \& } \\
\text { Hyslop } \\
(2015)\end{array}$ & $\begin{array}{l}\text { Empirical - } \\
\text { Qualitative }\end{array}$ & $\begin{array}{l}\text { A dyadic } \\
\text { cooperation } \\
\text { between } 2 \\
\text { family firms } \\
\text { Austria } \\
\end{array}$ & Primary & $\begin{array}{l}\text { Only } \\
\text { family } \\
\text { firms }\end{array}$ & $\begin{array}{l}\text { Resource } \\
\text { dependency } \\
\text { theory }\end{array}$ & $\begin{array}{l}\text { Inter-firm cooperation on a long-term } \\
\text { basis with learning and access to } \\
\text { knowledge, leading to innovation. }\end{array}$ & $\begin{array}{l}\text { (Findings) Trust embedded in the } \\
\text { collaboration eliminates the needs } \\
\text { for formalized contract. }\end{array}$ & N/A & $\mathrm{N} / \mathrm{A}$ & $\begin{array}{l}\text { The role of trust in } \\
\text { enabling family } \\
\text { firms to share. }\end{array}$ \\
\hline 15 & $\begin{array}{l}\text { Hausman } \\
(2005)\end{array}$ & $\begin{array}{l}\text { Empirical - } \\
\text { Qualitative }\end{array}$ & $\begin{array}{l}6 \text { family } \\
\text { firms, US } \\
\text { and Spain }\end{array}$ & $\begin{array}{l}\text { Primary } \\
\text { +second } \\
\text { ary data }\end{array}$ & $\begin{array}{l}\text { Only } \\
\text { family } \\
\text { firms }\end{array}$ & - & $\begin{array}{l}\text { Cooperation between firms to } \\
\text { commercialize technologies and } \\
\text { manage resources. }\end{array}$ & $\begin{array}{l}\text { (Findings) Having collaborative } \\
\text { relationship with other firms } \\
\text { influence the adoption of } \\
\text { innovation. }\end{array}$ & $\begin{array}{l}\text { Collaboration as } \\
\text { strategy in obtaining } \\
\text { know-how and new } \\
\text { technology. }\end{array}$ & N/A & N/A \\
\hline
\end{tabular}




\begin{tabular}{|c|c|c|c|c|c|c|c|c|c|c|c|}
\hline 16 & $\begin{array}{l}\text { Kim et al. } \\
(2004)\end{array}$ & $\begin{array}{l}\text { Empirical - } \\
\text { Mixed } \\
\text { method }\end{array}$ & $\begin{array}{l}19 \text { Emerging } \\
\text { markets }\end{array}$ & $\begin{array}{l}\text { Seconda } \\
\text { ry data }\end{array}$ & $\begin{array}{l}\text { Only } \\
\text { family } \\
\text { conglo } \\
\text { merate } \\
\text { s }\end{array}$ & $\begin{array}{l}\text { Growth } \\
\text { pattern }\end{array}$ & $\begin{array}{l}\text { Joint ventures, international alliances, } \\
\text { and licensing agreements. }\end{array}$ & $\begin{array}{l}\text { (Findings) Family Conglomerates } \\
\text { seek know-how and } \\
\text { technology through licensing } \\
\text { arrangements and JV with foreign } \\
\text { partners when face threat from } \\
\text { new entrants. }\end{array}$ & $\begin{array}{l}\text { Collaboration as } \\
\text { strategy in obtaining } \\
\text { know-how and new } \\
\text { technology. }\end{array}$ & N/A & N/A \\
\hline 17 & $\begin{array}{l}\text { Kontinen } \\
\text { and Ojala } \\
(2011)\end{array}$ & $\begin{array}{l}\text { Empirical - } \\
\text { Qualitative }\end{array}$ & $\begin{array}{l}8 \text { family } \\
\text { SMES, } 16 \\
\text { interviews, } \\
\text { manufacturin } \\
\text { g, Finland }\end{array}$ & $\begin{array}{l}\text { Primary } \\
\text { data }\end{array}$ & $\begin{array}{l}\text { Only } \\
\text { family } \\
\text { firms }\end{array}$ & Network & $\begin{array}{l}\text { Internationalization - measured by } \\
\text { entering a foreign country (France). }\end{array}$ & $\begin{array}{l}\text { (Findings) Family SMEs mainly } \\
\text { recognize international } \\
\text { opportunities by establishing new } \\
\text { formal ties, while informal ties and } \\
\text { family ties have less significant } \\
\text { role in providing international } \\
\text { opportunities. }\end{array}$ & N/A & N/A & $\begin{array}{l}\text { International } \\
\text { opportunity } \\
\text { recognition } \\
\text { through new } \\
\text { formal ties. }\end{array}$ \\
\hline 18 & $\begin{array}{l}\text { Kraus et al. } \\
\quad(2012)\end{array}$ & $\begin{array}{l}\text { Empirical - } \\
\text { Quantitative }\end{array}$ & $\begin{array}{l}533 \text { firms, } \\
\text { food, media } \\
\text { and maritime } \\
\text { industry, } \\
\text { Finland }\end{array}$ & $\begin{array}{l}\text { Primary } \\
\text { data }\end{array}$ & $\begin{array}{l}\text { Family } \\
\text { versus } \\
\text { nonfam } \\
\text { ily } \\
\text { firms }\end{array}$ & $\begin{array}{l}\text { Competitive } \\
\text { advantage }\end{array}$ & $\begin{array}{l}\text { Managing R\&D network to acquire } \\
\text { external knowledge. }\end{array}$ & $\begin{array}{l}\text { (Findings) A positive relationship } \\
\text { is found between managing } \\
\text { external relationships and } \\
\text { innovation performance. }\end{array}$ & $\begin{array}{l}\text { Organizational } \\
\text { innovation as } \\
\text { collaboration } \\
\text { capability in } \\
\text { managing external } \\
\text { relationships to } \\
\text { obtain external } \\
\text { knowledge and } \\
\text { achieve innovation. }\end{array}$ & N/A & N/A \\
\hline 19 & $\begin{array}{l}\text { Li et al. } \\
(2015)\end{array}$ & Review & China & - & - & $\begin{array}{l}\text { Competitive } \\
\text { advantage, } \\
\text { network }\end{array}$ & $\begin{array}{l}\text { Nonmarket social and political } \\
\text { network. }\end{array}$ & $\begin{array}{l}\text { (Conclusions) Family firms need } \\
\text { to expand beyond familism-based } \\
\text { social networks, such as alliances. }\end{array}$ & $\begin{array}{l}\text { The need to expand } \\
\text { beyond family-based } \\
\text { network into } \\
\text { cooperation and } \\
\text { alliance with external } \\
\text { parties to access } \\
\text { resources. }\end{array}$ & N/A & $\begin{array}{l}\text { The benefit of } \\
\text { nonmarket } \\
\text { network possessed } \\
\text { by family firms. }\end{array}$ \\
\hline 20 & $\begin{array}{l}\text { Miller et al. } \\
\text { (2009) }\end{array}$ & $\begin{array}{l}\text { Empirical - } \\
\text { Quantitative }\end{array}$ & $\begin{array}{l}170 \text { firms, } \\
\text { Korea }\end{array}$ & $\begin{array}{l}\text { Primary } \\
\text { data }\end{array}$ & $\begin{array}{l}\text { Family } \\
\text { versus } \\
\text { nonfam } \\
\text { ily } \\
\text { firms }\end{array}$ & $\begin{array}{l}\text { Organizational } \\
\text { commitment } \\
\text { to employees } \\
\text { (OCE) }\end{array}$ & $\begin{array}{l}\text { External relationship such as alliances } \\
\text { and JVs as opposed to "one shot" } \\
\text { transaction, supplying knowledge, } \\
\text { social, and financial capital. }\end{array}$ & $\begin{array}{l}\text { (Findings) Investment in } \\
\text { community and connection are } \\
\text { germane to success in emerging- } \\
\text { market and high-technology } \\
\text { environments, and both are more } \\
\text { helpful to family firms than to } \\
\text { nonfamily firms. }\end{array}$ & N/A & N/A & $\begin{array}{l}\text { The need for } \\
\text { investment in } \\
\text { network to be } \\
\text { innovative. }\end{array}$ \\
\hline 21 & $\begin{array}{l}\text { Nieto et al. } \\
\quad(2015)\end{array}$ & $\begin{array}{l}\text { Empirical - } \\
\text { Quantitative }\end{array}$ & $\begin{array}{l}15,173 \text { firms, } \\
\text { manufacturin } \\
\text { g, Spain }\end{array}$ & $\begin{array}{l}\text { Seconda } \\
\text { ry data }\end{array}$ & $\begin{array}{l}\text { Family } \\
\text { versus } \\
\text { nonfam } \\
\text { ily } \\
\text { firms } \\
\end{array}$ & $\begin{array}{l}\text { Innovation } \\
\text { behavior }\end{array}$ & $\begin{array}{l}\text { Equity-based agreements where firms } \\
\text { pool their capabilities (i.e., JVs), as } \\
\text { well as non-equity form of alliances. }\end{array}$ & $\begin{array}{l}\text { (Findings) Family influence has } \\
\text { negative effect on willingness to } \\
\text { collaborate and family firms are } \\
\text { significantly less prone to } \\
\text { collaborate technologically. }\end{array}$ & N/A & N/A & $\begin{array}{l}\text { The effect of } \\
\text { family influence } \\
\text { on willingness to } \\
\text { collaborate. }\end{array}$ \\
\hline 22 & $\begin{array}{l}\text { Pant and } \\
\text { Rajadhyaks } \\
\text { ha (1996) }\end{array}$ & $\begin{array}{l}\text { Empirical - } \\
\text { Qualitative }\end{array}$ & India & - & $\begin{array}{l}\text { Only } \\
\text { family } \\
\text { firms }\end{array}$ & - & $\begin{array}{l}\text { Alliances that provide cost-effective } \\
\text { platforms for entering new countries } \\
\text { and in return, foreign firms provide } \\
\text { access to international markets and } \\
\text { technologies. }\end{array}$ & $\begin{array}{l}\text { (Conclusions) The unique family } \\
\text { firm characteristics, e.g. } \\
\text { succession, authority, and } \\
\text { decision-maker are the things } \\
\text { foreign companies must watch out } \\
\text { for when partnering with them. }\end{array}$ & $\begin{array}{l}\text { The effect of family } \\
\text { firm characteristics } \\
\text { on forming } \\
\text { collaborations with } \\
\text { foreign firms. }\end{array}$ & N/A & N/A \\
\hline 23 & $\begin{array}{l}\text { Pérez } \\
(2007)\end{array}$ & Review & Spain & $\begin{array}{l}\text { Seconda } \\
\text { ry data }\end{array}$ & $\begin{array}{l}\text { Only } \\
\text { family } \\
\text { firms }\end{array}$ & $\begin{array}{l}\text { RBV, resource } \\
\text { dependency } \\
\text { theory, } \\
\text { network } \\
\text { theory }\end{array}$ & $\begin{array}{l}\text { Cooperation among family firms for } \\
\text { knowledge transfer and innovation. }\end{array}$ & $\begin{array}{l}\text { (Conclusions) Refers to the } \\
\text { survival of family firms, where } \\
\text { they cooperate among themselves } \\
\text { for knowledge transfer and } \\
\text { innovation. }\end{array}$ & $\begin{array}{l}\text { Collaboration as } \\
\text { strategy for } \\
\text { knowledge transfer } \\
\text { and innovation. }\end{array}$ & N/A & N/A \\
\hline
\end{tabular}




\begin{tabular}{|c|c|c|c|c|c|c|c|c|c|c|c|}
\hline 24 & $\begin{array}{l}\text { Pittino and } \\
\text { Visintin } \\
\text { (2011) }\end{array}$ & $\begin{array}{l}\text { Empirical - } \\
\text { Quantitative }\end{array}$ & $\begin{array}{l}272 \text { SMEs, } \\
\text { Italy }\end{array}$ & $\begin{array}{l}\text { Primary } \\
\text { data }\end{array}$ & $\begin{array}{l}\text { Family } \\
\text { versus } \\
\text { nonfam } \\
\text { ily } \\
\text { firms } \\
\end{array}$ & $\begin{array}{l}\text { Comparative } \\
\text { transaction } \\
\text { governance } \\
\text { mechanisms } \\
\text { and RBV } \\
\end{array}$ & $\begin{array}{l}\text { Inter-organizational cooperation } \\
\text { which organizations work together to } \\
\text { achieve a common goal. }\end{array}$ & $\begin{array}{l}\text { (Findings) Family firms are less } \\
\text { willing to collaborate compared to } \\
\text { nonfamily firms. Generation effect } \\
\text { and succession period have effect } \\
\text { on propensity to collaborate. }\end{array}$ & N/A & $\mathrm{N} / \mathrm{A}$ & $\begin{array}{l}\text { The generation } \\
\text { effect and } \\
\text { succession period } \\
\text { on the propensity } \\
\text { to collaborate. }\end{array}$ \\
\hline 25 & $\begin{array}{l}\text { Pittino et } \\
\text { al. }(2013)\end{array}$ & $\begin{array}{l}\text { Empirical - } \\
\text { Quantitative }\end{array}$ & $\begin{array}{l}508 \text { firms, } \\
259 \text { alliances, } \\
\text { Italy }\end{array}$ & $\begin{array}{l}\text { Primary } \\
\text { data }\end{array}$ & $\begin{array}{c}\text { Family } \\
\text { versus } \\
\text { nonfam } \\
\text { ily } \\
\text { firms } \\
\end{array}$ & $\begin{array}{l}\text { Innovation } \\
\text { strategies }\end{array}$ & Technological alliance. & $\begin{array}{l}\text { (Findings) Family firm increases } \\
\text { the likelihood of adopting } \\
\text { exploration-based technology } \\
\text { sourcing strategies. }\end{array}$ & $\begin{array}{l}\text { Strategies adopted by } \\
\text { family firms in } \\
\text { accessing technology } \\
\text { to pursue innovation. }\end{array}$ & N/A & to \\
\hline 26 & $\begin{array}{l}\text { Roessl } \\
(2005)\end{array}$ & Review & - & - & - & $\begin{array}{l}\text { Cooperation } \\
\text { capabilities }\end{array}$ & $\begin{array}{l}\text { Cooperation defined as the } \\
\text { coordinated behavior between agents, } \\
\text { the advantages will not manifest until } \\
\text { some point in the future, subject to the } \\
\text { (uncertain) behavior of the other } \\
\text { agent. }\end{array}$ & $\begin{array}{l}\text { (Conclusions) Typical } \\
\text { characteristics of family businesses } \\
\text { as factors that hinder or encourage } \\
\text { cooperation. }\end{array}$ & $\begin{array}{l}\text { The effects of family } \\
\text { firm characteristics } \\
\text { on the collaboration } \\
\text { capability. }\end{array}$ & $\mathrm{N} / \mathrm{A}$ & N/A \\
\hline 27 & $\begin{array}{l}\text { Serrano- } \\
\text { Bedia et al. } \\
\quad(2016)\end{array}$ & $\begin{array}{l}\text { Empirical - } \\
\text { Quantitative }\end{array}$ & $\begin{array}{l}110 \text { firms, } \\
\text { Spain }\end{array}$ & $\begin{array}{l}\text { Primary } \\
\text { data }\end{array}$ & $\begin{array}{l}\text { Family } \\
\text { versus } \\
\text { nonfam } \\
\text { ily } \\
\text { firms }\end{array}$ & $\begin{array}{l}\text { Transaction } \\
\text { cost } \\
\text { economies, } \\
\text { knowledge } \\
\text { based view }\end{array}$ & $\begin{array}{l}\text { Collaboration with external partner(s) } \\
\text { through contractual arrangements in } \\
\text { order to gain unrelated knowledge in } \\
\text { the firm's current areas or to use } \\
\text { knowledge that advances existing } \\
\text { technologies and products. }\end{array}$ & $\begin{array}{l}\text { (Findings) There is a positive } \\
\text { relationship between collaboration } \\
\text { and innovation performance, } \\
\text { although family involvement has a } \\
\text { negative moderating effect on the } \\
\text { relationship between use of } \\
\text { knowledge from collaboration and } \\
\text { innovation performance. }\end{array}$ & $\begin{array}{l}\text { Using collaboration } \\
\text { as a strategy in } \\
\text { obtaining external } \\
\text { knowledge in } \\
\text { achieving innovation. }\end{array}$ & $\begin{array}{l}\text { Family } \\
\text { involvement } \\
\text { exerts higher } \\
\text { transaction } \\
\text { costs of } \\
\text { collaborations. }\end{array}$ & N/A \\
\hline 28 & $\begin{array}{l}\text { Singh and } \\
\text { Gaur } \\
(2013)\end{array}$ & $\begin{array}{l}\text { Empirical - } \\
\text { Quantitative }\end{array}$ & $\begin{array}{l}16,337 \text { firm- } \\
\text { year } \\
\text { observations } \\
\text { over eight } \\
\text { years, India }\end{array}$ & $\begin{array}{l}\text { Seconda } \\
\text { ry data }\end{array}$ & $\begin{array}{l}\text { Family } \\
\text { versus } \\
\text { nonfam } \\
\text { ily } \\
\text { firms } \\
\end{array}$ & Governance & $\begin{array}{l}\text { Business group - a set of legally } \\
\text { independent entities that share formal } \\
\text { and informal linkages and take } \\
\text { coordinated actions in multiple } \\
\text { product and/or geographic markets. }\end{array}$ & $\begin{array}{l}\text { (Findings) A positive effect of } \\
\text { family ownership and group } \\
\text { affiliation on R\&D intensity and } \\
\text { new foreign investments. }\end{array}$ & $\begin{array}{l}\text { The effect of family } \\
\text { ownership on the } \\
\text { ability to collaborate. }\end{array}$ & N/A & N/A \\
\hline 29 & $\begin{array}{l}\text { Sirmon and } \\
\text { Hitt (2003) }\end{array}$ & Review & - & - & - & RBV & $\begin{array}{l}\text { Formal alliances, such as JVs and } \\
\text { nonequity ventures, or informal } \\
\text { collaborations. }\end{array}$ & $\begin{array}{l}\text { (Conclusions) Effective } \\
\text { management of social capital in } \\
\text { family firmss leads to effective } \\
\text { utilization of alliances, allowing } \\
\text { for access to external resources. }\end{array}$ & $\begin{array}{l}\text { The effect of unique } \\
\text { family resources on } \\
\text { social capital } \\
\text { management, in } \\
\text { relation to } \\
\text { collaboration } \\
\text { capability. } \\
\end{array}$ & $\mathrm{N} / \mathrm{A}$ & N/A \\
\hline 30 & $\begin{array}{l}\text { Sirmon et } \\
\text { al. (2008) }\end{array}$ & $\begin{array}{l}\text { Empirical - } \\
\text { Quantitative }\end{array}$ & $\begin{array}{l}\text { 2,531 SMEs, } \\
\text { manufacturin } \\
\text { g, France }\end{array}$ & $\begin{array}{l}\text { Seconda } \\
\text { ry data }\end{array}$ & $\begin{array}{l}\text { Family } \\
\text { versus } \\
\text { nonfam } \\
\text { ily } \\
\text { firms }\end{array}$ & $\begin{array}{l}\mathrm{RBV} \& \text { threat } \\
\text { rigidity }\end{array}$ & $\begin{array}{l}\text { Internationalization - measured by } \\
\text { selling outside home country. }\end{array}$ & $\begin{array}{l}\text { (Findings) Family firms that } \\
\text { respond to high imitability with } \\
\text { higher levels of R\&D investments } \\
\text { and internationalization achieve } \\
\text { higher levels of firm performance, } \\
\text { as internationalization provides } \\
\text { access to new knowledge. }\end{array}$ & $\begin{array}{l}\text { The effect of family } \\
\text { influence on adopting } \\
\text { internationalization } \\
\text { for knowledge } \\
\text { access. }\end{array}$ & $\mathrm{N} / \mathrm{A}$ & N/A \\
\hline 31 & $\begin{array}{l}\text { Sorenson et } \\
\text { al. (2008) }\end{array}$ & $\begin{array}{l}\text { Empirical - } \\
\text { Quantitative }\end{array}$ & $\begin{array}{l}193 \\
\text { questionnaire } \\
\text { s, US }\end{array}$ & $\begin{array}{l}\text { Primary } \\
\text { data }\end{array}$ & $\begin{array}{l}\text { Only } \\
\text { family } \\
\text { firms }\end{array}$ & $\begin{array}{l}\text { Collaborative } \\
\text { network } \\
\text { orientation } \\
(\mathrm{CNO}) \\
\end{array}$ & $\begin{array}{l}\text { Collaborative relationships among } \\
\text { networks made up of customers, } \\
\text { family members, community } \\
\text { members, and, inside the } \\
\text { organization, employees. }\end{array}$ & $\begin{array}{l}\text { (Findings) Collaborative network } \\
\text { orientation is positively associated } \\
\text { with business performance for both } \\
\text { female and male managers. }\end{array}$ & $\mathrm{N} / \mathrm{A}$ & $\begin{array}{l}\text { The positive } \\
\text { effect of } \\
\text { collaboration } \\
\text { on firm } \\
\text { performance. }\end{array}$ & N/A \\
\hline
\end{tabular}




\begin{tabular}{|c|c|c|c|c|c|c|c|c|c|c|c|}
\hline 32 & $\begin{array}{l}\text { Spriggs et } \\
\text { al. (2012) }\end{array}$ & $\begin{array}{l}\text { Empirical - } \\
\text { Quantitative }\end{array}$ & $\begin{array}{l}199 \\
\text { questionnaire } \\
\text { s, US }\end{array}$ & $\begin{array}{l}\text { Primary } \\
+ \text { second } \\
\text { ary data }\end{array}$ & $\begin{array}{l}\text { Only } \\
\text { family } \\
\text { firms }\end{array}$ & RBV & $\begin{array}{l}\text { Collaborative network, such as } \\
\text { customers. }\end{array}$ & $\begin{array}{l}\text { (Findings) No moderation effect of } \\
\text { collaborative network orientation } \\
\text { found on innovative capacity and } \\
\text { firm performance. }\end{array}$ & N/A & $\begin{array}{l}\text { The interaction } \\
\text { effect of } \\
\text { innovative } \\
\text { capacity and } \\
\text { collaborative } \\
\text { network } \\
\text { orientation on } \\
\text { firm } \\
\text { performance. }\end{array}$ & N/A \\
\hline 33 & $\begin{array}{l}\text { Stanley and } \\
\text { McDowell } \\
\text { (2014) }\end{array}$ & $\begin{array}{l}\text { Empirical - } \\
\text { Quantitative }\end{array}$ & $\begin{array}{c}149 \\
\text { questionnaire } \\
\text { s, supplier to } \\
\text { university, } \\
\text { US } \\
\end{array}$ & $\begin{array}{l}\text { Primary } \\
\text { data }\end{array}$ & $\begin{array}{c}\text { Family } \\
\text { versus } \\
\text { nonfam } \\
\text { ily } \\
\text { firms } \\
\end{array}$ & $\begin{array}{c}\text { Social capital: } \\
\text { organizational } \\
\text { efficacy and } \\
\text { interorganizati } \\
\text { onal trust } \\
\end{array}$ & Partnership with customer/supplier. & $\begin{array}{l}\text { (Findings) Positive relationship } \\
\text { between interorganizational trust } \\
\text { and performance in both family } \\
\text { and nonfamily firms. }\end{array}$ & N/A & $\begin{array}{l}\text { The effect of } \\
\text { interorganizatio } \\
\text { nal trust on } \\
\text { firm } \\
\text { performance. } \\
\end{array}$ & N/A \\
\hline 34 & $\begin{array}{l}\text { Tsao and } \\
\text { Lien (2013) }\end{array}$ & $\begin{array}{l}\text { Empirical - } \\
\text { Quantitative }\end{array}$ & $\begin{array}{l}3,103 \text { firm- } \\
\text { year } \\
\text { observations } \\
\text { with } 776 \\
\text { firms, } \\
\text { Taiwan }\end{array}$ & $\begin{array}{l}\text { Seconda } \\
\text { ry data }\end{array}$ & $\begin{array}{l}\text { Family } \\
\text { versus } \\
\text { nonfam } \\
\text { ily } \\
\text { firms }\end{array}$ & Agency theory & $\begin{array}{l}\text { Internationalization - measured by } \\
\text { ratio of foreign sales to total sales, } \\
\text { ratio of foreign assets to total assets, } \\
\text { and the number of countries where a } \\
\text { firm operates. }\end{array}$ & $\begin{array}{l}\text { (Findings) Family management } \\
\text { and ownership positively moderate } \\
\text { the performance and innovation } \\
\text { implications of } \\
\text { internationalization. }\end{array}$ & $\begin{array}{l}\text { The role of family } \\
\text { ownership and } \\
\text { management on } \\
\text { mitigating negative } \\
\text { effects and extracting } \\
\text { benefits of } \\
\text { internationalization. }\end{array}$ & $\begin{array}{l}\text { Performance } \\
\text { implications of } \\
\text { internationaliza } \\
\text { tion. }\end{array}$ & N/A \\
\hline 35 & $\begin{array}{l}\text { Yeoh } \\
(2014)\end{array}$ & $\begin{array}{l}\text { Empirical - } \\
\text { Quantitative }\end{array}$ & $\begin{array}{l}110 \mathrm{FB} \\
\text { SMEs, } \\
\text { electronic } \\
\text { and electrical } \\
\text { industry, } \\
\text { Malaysia } \\
\end{array}$ & $\begin{array}{l}\text { Primary } \\
\text { data }\end{array}$ & $\begin{array}{l}\text { Only } \\
\text { family } \\
\text { firms }\end{array}$ & $\begin{array}{l}\text { Competitive } \\
\text { advantage }\end{array}$ & $\begin{array}{l}\text { Relationships with external entities } \\
\text { (e.g., partnerships, suppliers, and } \\
\text { research institutes). }\end{array}$ & $\begin{array}{l}\text { (Findings) External CEO's } \\
\text { international experience has } \\
\text { positive effect on sourcing external } \\
\text { technology and financial } \\
\text { performance. }\end{array}$ & $\begin{array}{l}\text { Hiring external CEO } \\
\text { with international } \\
\text { experience as a } \\
\text { strategy in obtaining } \\
\text { external source of } \\
\text { technology. }\end{array}$ & $\mathrm{N} / \mathrm{A}$ & N/A \\
\hline 36 & $\begin{array}{l}\text { Zahra } \\
(2010)\end{array}$ & $\begin{array}{l}\text { Empirical - } \\
\text { Quantitative }\end{array}$ & $\begin{array}{l}779 \\
\text { responses, } \\
\text { manufacturin } \\
\text { g industries, } \\
\text { US }\end{array}$ & $\begin{array}{l}\text { Primary } \\
\text { data }\end{array}$ & $\begin{array}{l}\text { Only } \\
\text { family } \\
\text { firms }\end{array}$ & $\begin{array}{l}\text { Relational } \\
\text { perspective }\end{array}$ & $\begin{array}{l}\text { Organizational social capital (OSC) as } \\
\text { a result of family firms' interactions, } \\
\text { communications and relationships } \\
\text { with diverse external stakeholders, } \\
\text { and allows family firms to obtain } \\
\text { resources through these channels. }\end{array}$ & $\begin{array}{l}\text { (Findings) Family firms use their } \\
\text { OSC to develop alliances and JVs } \\
\text { with new ventures, as these } \\
\text { alliances are a key source of } \\
\text { learning and achieving innovation. }\end{array}$ & N/A & N/A & $\begin{array}{l}\text { Exploiting family } \\
\text { firms' social } \\
\text { capital. }\end{array}$ \\
\hline 37 & $\begin{array}{l}\text { Zamudio et } \\
\text { al. (2014) }\end{array}$ & Review & - & - & - & $\begin{array}{l}\text { Social capital, } \\
\text { network }\end{array}$ & $\begin{array}{l}\text { Collaborations, internationalization, } \\
\text { and network. }\end{array}$ & $\begin{array}{l}\text { (Conclusions) There is a need to } \\
\text { further examine network and social } \\
\text { capital, how family firms } \\
\text { collaborate with external firms and } \\
\text { generate competitive advantage. }\end{array}$ & N/A & N/A & $\begin{array}{l}\text { Family firms } \\
\text { collaborating with } \\
\text { external firms } \\
\text { through their } \\
\text { network and social } \\
\text { capital. } \\
\end{array}$ \\
\hline
\end{tabular}


Figure 2. Framework on Collaborative Innovation with Major Constructs and Relationships

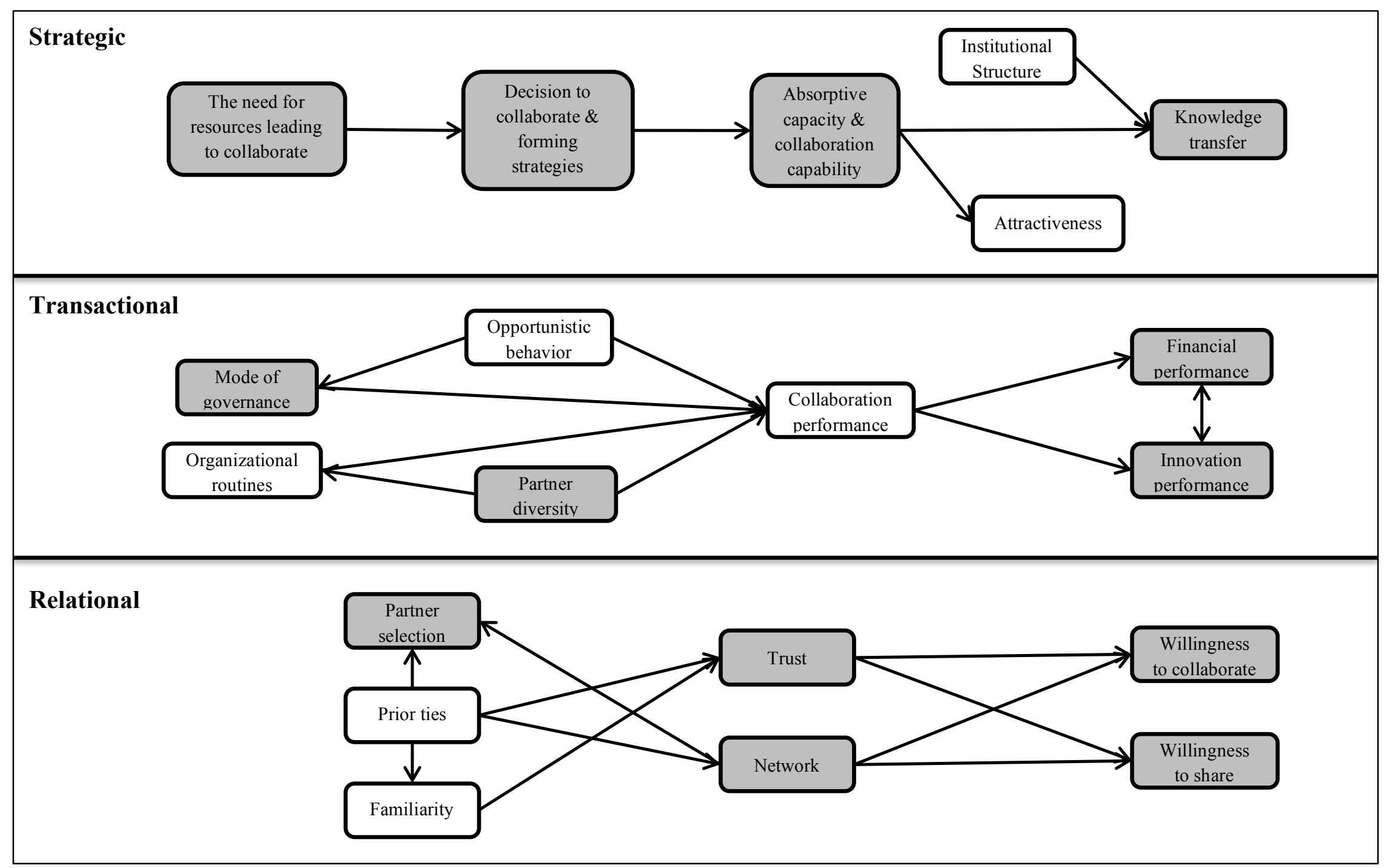

Note: Grey color boxes indicate topics that have been addressed in the extant family business literature. 